\title{
The first lower Viséan trilobite association from limestone facies of the Moravian Karst and its relation to the sedimentary environment (Líšeň Formation, Czech Republic)
}

\author{
Tomáš Weiner, Hedvika Weinerová, JiŘí Kalvoda \& Tomáš VikTorÝn
}

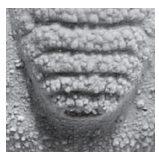

\begin{abstract}
A lower Viséan trilobite association from limestones of the Líšeň Formation in the Moravian Karst (Czech Republic) was studied in detail for the first time. The trilobites were obtained from a thin interval in the succession of the HádyŘíčka Limestone exposed in the Zetor section situated on the southern margin of the Moravian Karst near Brno. The limestone succession of the Zetor section with prevalently distal calciturbidites was deposited on the lower part of the carbonate ramp. Biostratigraphic data suggest the span of the lower Viséan MFZ11 (foraminiferal zone) for the interval rich in trilobites. The trilobites are preserved in at least a partly silicified state. Around twenty trilobite species or subspecies were recorded including one new taxon Bollandia megaira brunensis subsp. nov., various species of ?Namuropyge R. Richter \& E. Richter, Liobole R. Richter \& E. Richter, Angustibole G. Hahn, ?Cyrtoproetus Reed, Gitarra Gandl, Pseudowaribole (Geigibole) Gandl, Winterbergia G. Hahn \& Brauckmann, Bollandia Reed and several taxa of problematic affinity, which are discussed. The recorded taxa show an affinity with associations from the Erdbach Limestone facies in Germany but also with other areas (e.g. Cantabrian Mountains, Spain). The trilobite association shows similarities to the "Shelf Slope" and "Erdbacher Kalke" communities recorded in Germany. In contrast, the previously described lower Viséan trilobite associations from the Moravian Karst were restricted to the aleuropelitic facies of the Březina Formation and correspond rather to the "Culm facies" community known from Germany. These associations might represent more distal and deeper basinal settings than the Zetor section or an environment of generally similar depths with a different source area and bottom topography. Key words: trilobites, microfacies, lower Carboniferous, Viséan, Líšeň Formation, Moravian Karst.
\end{abstract}

\begin{abstract}
Weiner, T., Weinerová, H., Kalvoda, J. \& Viktorýn, T. 2021. The first lower Viséan trilobite association from limestone facies of the Moravian Karst and its relation to the sedimentary environment (Lišen Formation, Czech Republic). Bulletin of Geosciences 96(2), 217-249 (12 figures, electronic supplement). Czech Geological Survey, Prague. ISSN 1214-1119. Manuscript received August 7, 2020; accepted in revised form March 19, 2021; published online April 11, 2021; issued April 11, 2021.
\end{abstract}

Tomáš Weiner, Czech Academy of Sciences, Institute of Geology, Rozvojová 269, 16500 Prague 6, Czech Republic; weiner@gli.cas.cz • Hedvika Weinerová, Czech Academy of Sciences, Institute of Geology, Rozvojová 269,16500 Prague 6, Czech Republic \& Department of Geological Sciences, Faculty of Science, Masaryk University, Kotlár ská 2, 61137 Brno, Czech Republic • Jiři Kalvoda, Department of Geological Sciences, Faculty of Science, Masaryk University, Kotlářská 2, 61137 Brno, Czech Republic • Tomáš Viktorýn, Slavkovská 9, 62700 Brno-Slatina, Czech Republic

The trilobites from the Moravian Karst facies domain of the Moravosilesian Basin have been studied from various localities and across the Middle to Upper Devonian and lower Carboniferous (Chlupáč 1966, 1969, 1992; Rak et al. 2012, 2014; Weiner et al. 2012). Givetian limestones near Čelechovice contain rather abundant trilobites belonging to several species (for summary see Chlupáč 1992), whereas the Frasnian limestones of the Moravian Karst development are generally poor in trilobites and only a few rare specimens have been mentioned or described in the literature (Oppenheimer 1930, Chlupáč
1966, Hladil 1983, Weiner et al. 2018). In total, around sixty trilobite species or subspecies are known from Famennian, Tournaisian and Viséan in the southern part of the Moravian Karst, and especially from various localities in the northeastern vicinity of Brno (Chlupác 1966, 1969; Rak et al. 2012, 2014; Weiner et al. 2012). Famennian trilobites are described from limestones of the Líšeň Formation (Chlupáč 1966, 2000), and Tournaisian trilobites are known from the limestones or aleuropelitic facies of both the Líšeň and Březina formations (Chlupáč 1966, Rak et al. 2012). The trilobite species and sub- 
species from the lower part of the Viséan (= Lower to Middle Viséan, ?or up to the lowermost Upper Viséan, cu II $\gamma-\delta$ stage, see Fig. 1E) have only been described from the aleuropelitic facies of the Březina Formation (Chlupác 1966, 1969; Kalvoda et al. 2010; Weiner et al. 2012; Rak et al. 2014). In this paper, the first lower Viséan trilobite association from limestone facies of the Lišeň Formation is described and discussed. Sedimentological data are used to better understand the palaeoenvironmental conditions of trilobite fauna.

\section{Geological setting}

The Zetor section is located in the southern part of the Moravian Karst. The $4.25 \mathrm{~m}$ thick sedimentary succession described below $\left(49^{\circ} 11^{\prime} 38.6^{\prime \prime} \mathrm{N}, 16^{\circ} 11^{\prime} 33.4^{\prime \prime} \mathrm{E}\right)$ is situated in a small abandoned quarry in a grove surrounded by fields at the eastern margin of Brno (Fig. 1A, B). Outcrops of the lower Carboniferous Hády-Říčka Limestone of the Líšeň Formation are exposed here (Synek 1997, 1999). The succession was deposited in the outer carbonate apron environment sensu Mullins \& Cook (1986) with distal calciturbidites and a few calciturbidites of more proximal character (see Synek 1997, 1999; Poukarová 2014).

The Devonian and lower Carboniferous pre-flysch sediments of the Moravian Karst were deposited in the Moravosilesian Basin on the southern margin of Laurussia and represent an eastern continuation of the Rhenohercynian Zone (e.g. Franke 1989; Kalvoda 1998; Kalvoda et al. 2002, 2003, 2008). These strata form a sedimentary cover of Brunovistulian terrane within the eastern part of the Bohemian Massif. Several similar lithostratigraphic schemes have been published for the Devonian and Carboniferous in the Moravian Karst (e.g. Chlupáč 1966; Kalvoda et al. 2008, 2010; see Fig. $1 \mathrm{C}, \mathrm{D})$.

The Moravosilesian Basin was facially differentiated: the Moravian Karst (platform) development, Ludmírov (transitional) development and Drahany (basin) development represent three major facies domains (Chlupáč 1965, 1988; Hladil 1992).

The carbonate platform of the Moravian Karst facies domain was progressively destroyed during the Frasnian and Famennian, which led to the development of half-grabens and sedimentation in a carbonate ramp environment (Hladil et al. 1991, Kalvoda 1998, Bábek et al. 2007, Kalvoda et al. 2008). In the southern part of the Moravian Karst, various limestones of the Líšen Formation, especially calciturbidites and hemipelagites persisted from the Famennian to Tournaisian and the lower part of the Viséan (Fig. 1C, D). Two main limestone lithologies can be distinguished in this interval: 1) dark grey to black platy limestones, locally with thin shale intercalations and cherts, mainly representing calciturbidites, known as Hády-Říčka Limestone, and 2) medium to dark grey, reddish, greenish or locally variegated, commonly nodular, bedded to massive limestones known as Krrtiny Limestone, which are often supposed to represent mainly hemipelagites and muddy calciturbidites (e.g. Kalvoda et al. 2008, 2015; Rez et al. 2011). During the upper Tournaisian and lower Viséan, the carbonate sediments of the Lišeň Formation were laterally and vertically replaced by the Březina Formation, which is represented mainly by greenish, reddish or brownish aleuropelitic shales, locally alternating with limestone layers (Kalvoda et al. 2010). The Březina Formation is considered to reflect a transitional phase between a "pre-flysch" Moravian Karst "platform" development, represented mainly by limestones and flysch of the siliciclastic "Culm facies" characterised by overlying successions of the Rozstání and Myslejovice formations (e.g. Kalvoda et al. 2010, Rez et al. 2011).

\section{Material and Methods}

The Zetor section was investigated and described in a bed-by-bed manner. Samples for microfacies analysis were taken with an average vertical step of $35 \mathrm{~cm}$ and cut perpendicular to the bedding. In total, 30 standard-sized $(40 \times 25 \times 0.03 \mathrm{~mm})$ thin sections from 12 beds were examined. Microfacies were observed under a Nikon Eclipse 80i polarising microscope. Photographs were taken using Nikon DXM digital camera and NIS Elements software.

The carbonate classification of Embry \& Klovan (1971) was followed. Quantitative data for the limestone composition were obtained using the point-count method applied on three microphotographs each of 12 selected thin sections, using the JMicroVision image analysis software (Nicolas Roduit, Switzerland). Each thin section was examined via 300 randomly generated points classified into 23 categories (see electronic supplement) using grain-bulk measurement method. The statistical confidence of this approach was checked via an evolution plot (JMicroVision). The data obtained, expressed in percentages (\%), were subjected to principal component analysis (PCA) via Statistica12 software, using a correlation matrix. Abbreviation used: " $\%$ al $" \approx$ "\% of allochems (non-skeletal grains + bioclasts)".

Foraminifers were studied in thin sections. Conodont elements were obtained using a standard technique: limestone samples were etched in $15 \%$ acetic acid. Conodonts and silicified trilobites were separated from the insoluble residuum after the dissolution process.

The trilobite remnants are prevalently imperfectly silicified but the extent of this preservation varied in the 

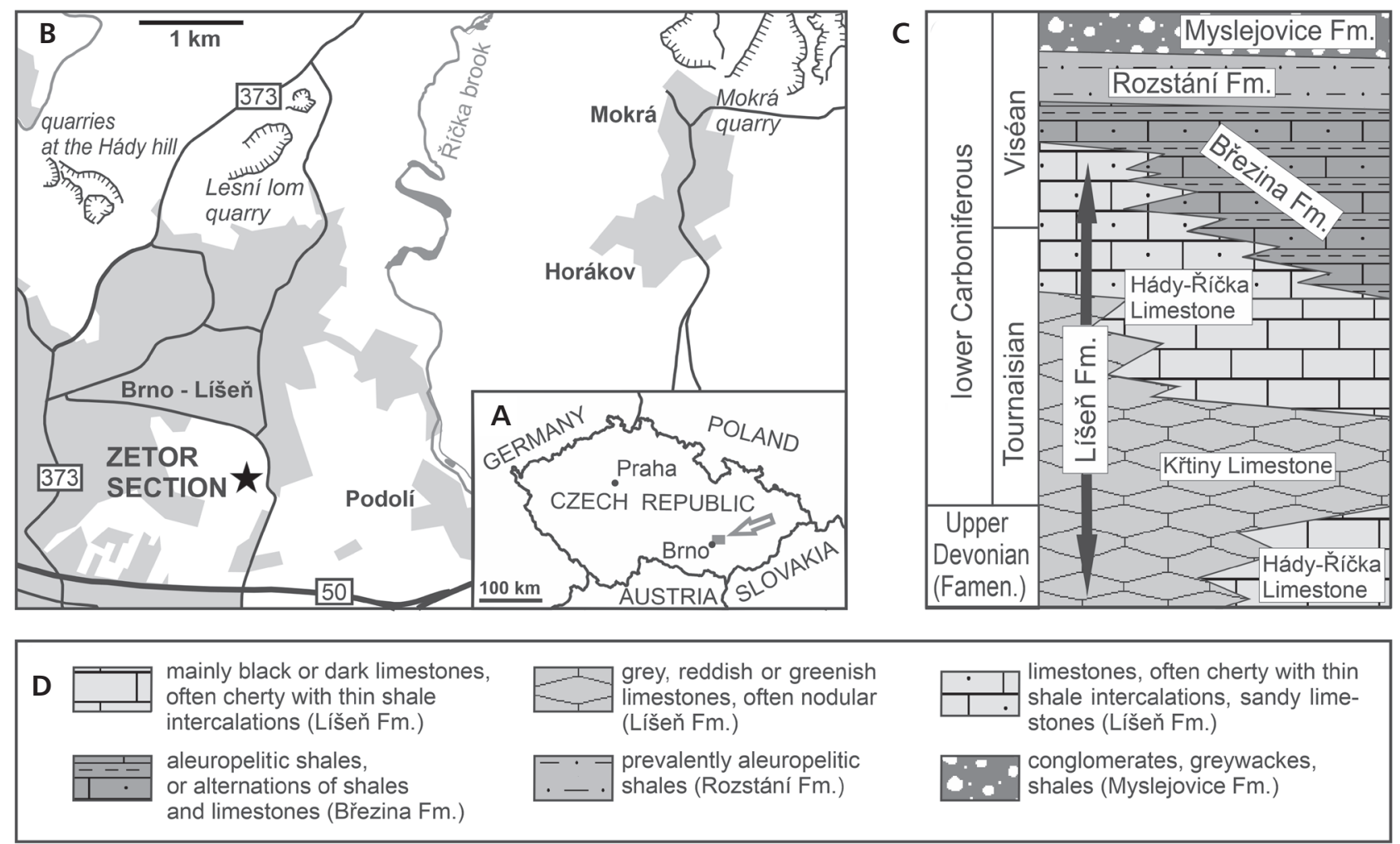

E

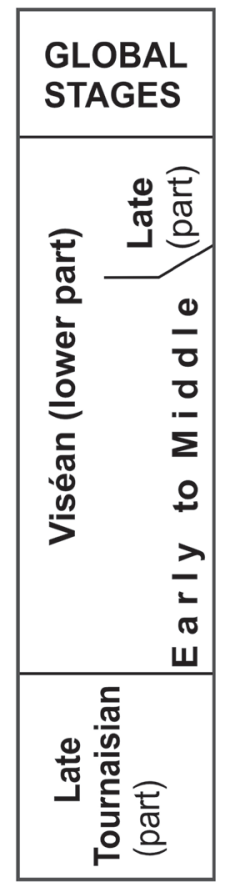

\begin{tabular}{|c|c|}
\hline $\begin{array}{c}\text { BELGIAN } \\
\text { SUBSTAGES }\end{array}$ & FORAMINIFERS \\
\hline $\begin{array}{c}\text { Warnantian } \\
\text { (part) }\end{array}$ & MFZ14 \\
\cline { 2 - 2 } Livian & MFZ13 \\
\hline \multirow{4}{*}{ Moliniacian } & MFZ12 \\
\cline { 2 - 2 } & MFZ10 \\
\cline { 2 - 2 } & MFZ9 \\
\hline \multirow{3}{*}{ Ivorian (part) } & MFZ8 \\
\cline { 2 - 2 } & MFZ6 \\
\cline { 2 - 2 } & MFZ5 \\
\hline
\end{tabular}

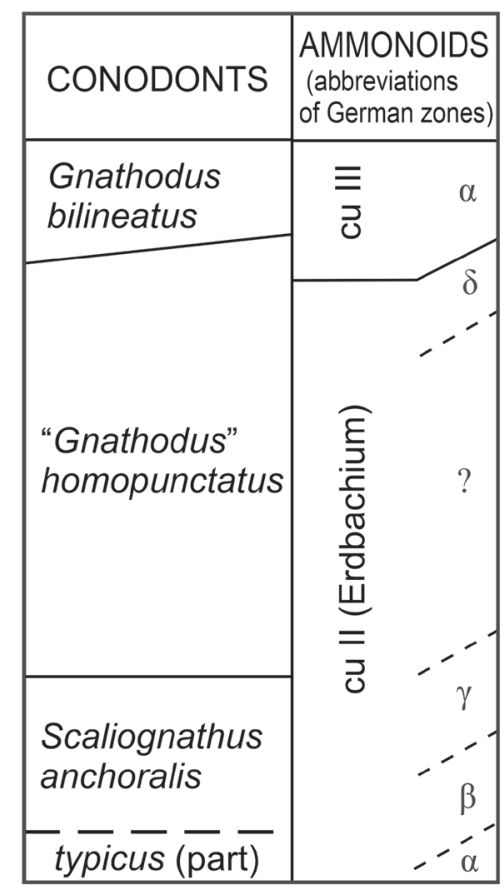

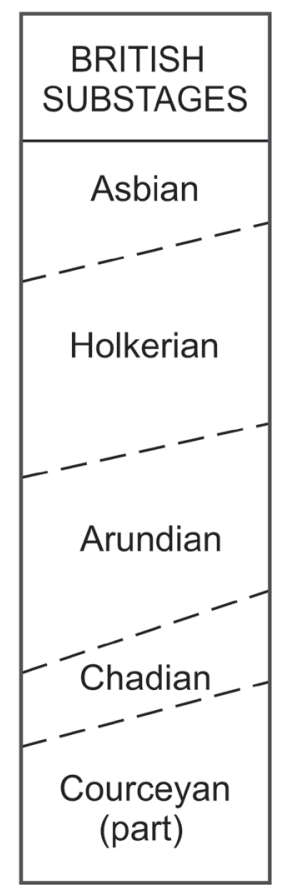

Figure 1. Geographic position and lithostratigraphy of the studied area. $\cdot \mathrm{A}-$ geographic position of northeastern vicinity of Brno within the Czech Republic marked by grey arrow and rectangle. $\bullet \mathrm{B}-$ schematic map of northeastern vicinity of Brno, geographic position of the Zetor section marked by black star. $-\mathrm{C}$ - lithostratigraphic scheme of the uppermost Devonian and lower Carboniferous in southern part of the Moravian Karst (after Kalvoda et al. 2010, modified). • D - explanations of lithological symbols. $・$ E - schematic correlation of various regional substages and zonations in the lower Viséan and upper Tournaisian. Global stages, regional substages and foraminifer zones were compiled from Poty et al. (2006), Poty et al. (2014), Vachard et al. (2018a) and Müller \& Hahn (2018). Conodont zones were compiled from Herbig (2016). Abbreviated ammonoid zones were compiled from Korn \& Gereke (in Amler \& Gereke 2002). Abbreviations: Famen. - Famennian; Fm. - formation; MFZ - Mississippian Foraminifer Zones. 
obtained specimens. As observed in thin sections (Fig. 3F) and specimens obtained from insoluble residuum, the silicification started on both the lower and upper external surfaces of the previous calcareous fossilisation of trilobite exoskeletons. The inner portions of the exoskeleton often remained calcareous/not silicified. The thicker and larger parts of exoskeletons tended to more commonly have calcareous inner portions and partly calcareous and silicified surface portions whereas smaller and thinner specimens were often more completely silicified. This means that smaller specimens were less fragmented in insoluble residuum and more complete larger holaspid parts of exoskeleton were very rarely obtained (Figs 5A, $\mathrm{B} ; 10 \mathrm{C}-\mathrm{G})$. The fragmentation of trilobites in insoluble residuum is also affected by common calcite veins. Larger specimens were therefore preferably mechanically prepared and not macerated in acetic acid.

The morphological terms are mostly following Whittington \& Kelly (1997). The Greek letters used for the description of facial suture correspond to schemes of Hahn \& Hahn (1975, p. 20, fig. 1) and Müller \& Hahn (2018, p. 15, fig. 3). Following abbreviations are used for the measurements of parts of the exoskeleton or articulated specimens: SL - complete sagittal length; ISL incomplete sagittal length; ESL - estimated complete sagittal length; LA - longest axis of complete part of the exoskeleton; ILA - longest axis of incomplete part of the exoskeleton; ELA - estimated longest axis of complete part of the exoskeleton (if preserved as incomplete).

The trilobites from the Zetor section discussed in this paper were deposited at the Czech Geological Survey, Prague, Czech Republic (inventory numbers CGS TW500-586).

\section{Results}

\section{Lithology and sedimentary environment}

All trilobite material presented in the systematic part comes from $c a 30 \mathrm{~cm}$ thick interval of distinct character within the studied $425 \mathrm{~cm}$ thick succession of the Hády-Říčka Limestone (Figs 2A, 4). We failed to macroscopically discover trilobites in other parts of the section in the field. All trilobite remnants recorded outside the mentioned $c a$ $30 \mathrm{~cm}$ thick interval are represented by rare microscopic fragments in thin sections. The facies and microfacies analysis was of importance for understanding the origin and depositional environment of trilobite-bearing interval.

The section is dominated by very thin-/medium-bedded grey laminated calcisiltites to fine-grained calcarenites with cherts. We failed to discover macrofossils in these beds in the field. Three beds with sharp bases and positive gradation with calcarenite/fine-grained calcirudite at the base are developed in the lower part of the section: intraclasts and some macrofossils including crinoids and gastropods were observed in the calcirudite in the field.

The trilobite-bearing interval lies between 300 and $330 \mathrm{~cm}$ above base of the section and immediately overlies about $4 \mathrm{~cm}$ thick layer characterized by common crinoid columnals and multicolumnals reaching up to $2 \mathrm{~cm}$ in diameter. The trilobite-bearing interval is considerably weathered. It consists of light grey marlstone with discontinuous layers of light grey calcisiltite to fine-grained calcirudite containing common macrofossils (trilobites, crinoids, molluscs, brachiopods, rugose corals), grey calcisiltites to fine-grained calcarenites with cherts, and limonite concretions. Insoluble residuum was rich in silicified fossils, especially trilobites and ostracods.

The quantitative microfacies data (Fig. 2A) were subjected to principal component analysis (PCA), which reveals relationships among carbonate components (Fig. 2B) and enabled four microfacies types to be established (Fig. 2C).

Microfacies A. - The microfacies (Z4b; Fig. 3A, E) was obtained from calcirudite at the base of the graded bed and correspond to partly silicified floatstone with packstone matrix. Grains $>2 \mathrm{~mm}$ include some intraclasts and bioclasts. Matrix contains $24 \%$ micrite/microsparite, $8 \%$ sparite, $63 \%$ allochems and detrital quartz (5\%). Nonskeletal grains such as ooids $\left(21 \%_{a 1}\right)$, peloids $\left(11 \%_{a 1}\right)$, cortoids $\left(9 \%_{\mathrm{al}}\right)$ and intraclasts $\left(9 \%_{\mathrm{al}}\right)$ are common. Bioclasts are represented mainly by crinoids $\left(21 \%_{\mathrm{al}}\right)$ and various multilocular foraminifers $\left(7 \%_{\mathrm{al}}\right)$, but bryozoans, brachiopods, trilobites, molluscs, moravamminid/echinoderm hash, Pachysphaerina sp., benthic calcifying green algae, corals, ostracods, red algae, Earlandia sp., moravamminids and calcispheres also occur. Intraclasts mostly correspond to microfacies $\mathrm{C}$ and mudstone/ wackestone with radiolarians (see Fig. 3E). Ooids consist of concentric laminae around nuclei represented by foraminifers or crinoid ossicles.

Interpretation: The microfacies was obtained from calciturbidite which contains material derived from very shallow environment, probably oolitic shoal (Fig. 12A), as suggested by common ooids, micritisation products (cortoids, peloids), relatively large detrital quartz grains, and presence of benthic calcifying algae. Multilocular foraminifers are represented also by taxa adapted to highenergy environments, e.g. Omphalotis (see Gallagher 1998).

Microfacies B. - The microfacies (Z3; Fig. 3B, F) comes from calcarenite at the base of the graded bed. This packstone contains $14 \%$ micrite/microsparite, $26 \%$ sparite, $62 \%$ allochems and rare grains of detrital quartz. Non- 


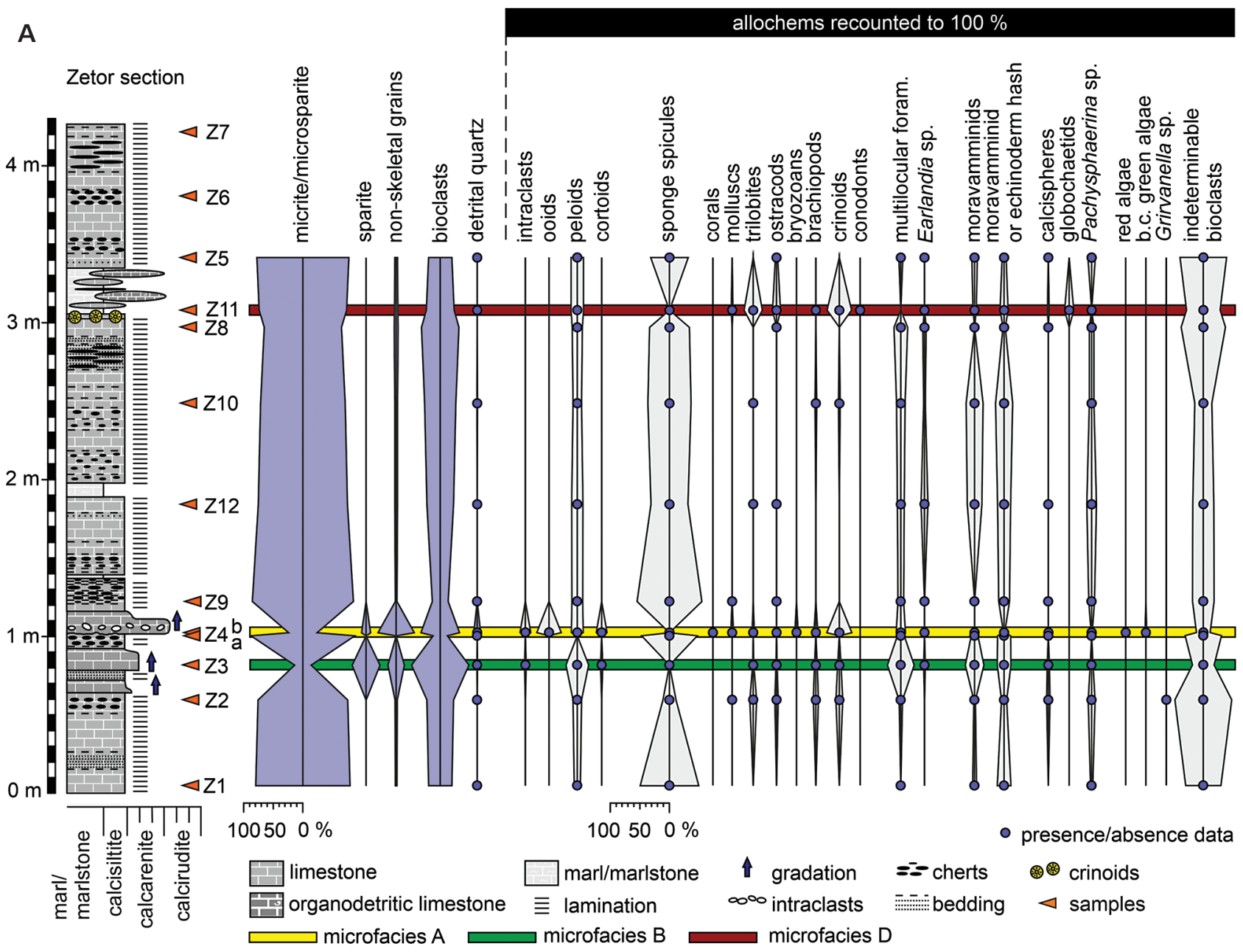

B

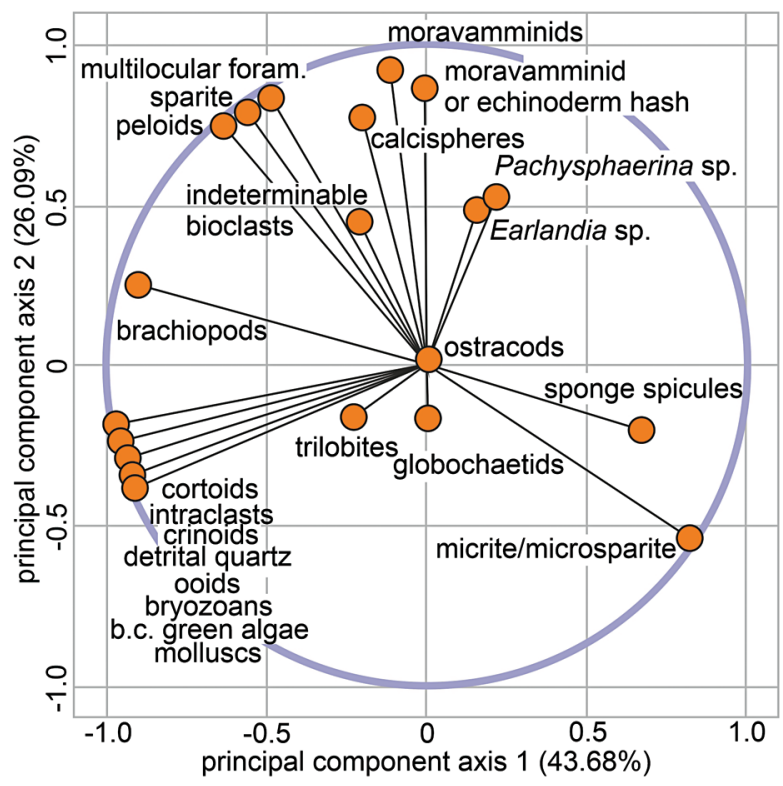

C

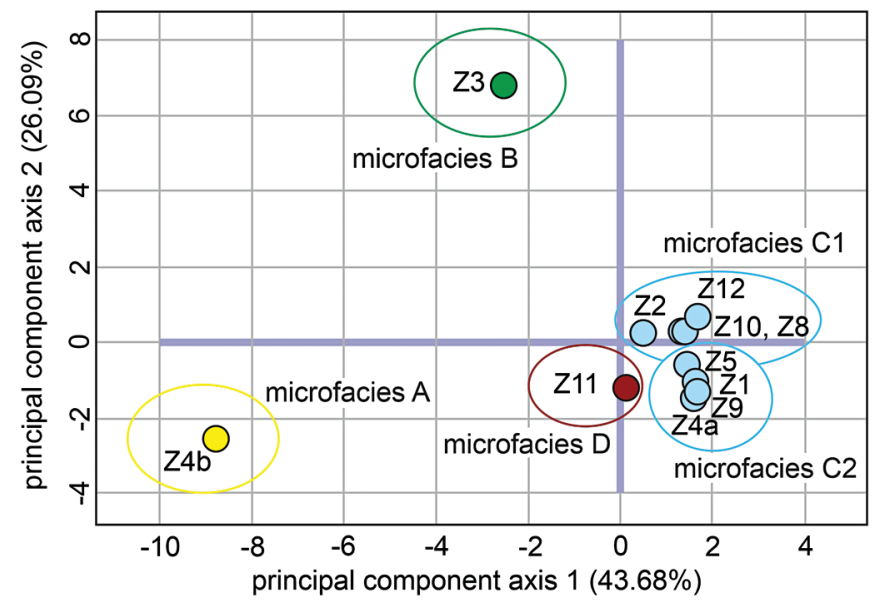

Figure 2. Zetor section. - A - quantitative microfacies analysis and presence/absence data, based on observations of thin sections. • B - principal component analysis (PCA) showing relationships among carbonate components. $\bullet \mathrm{C}-$ principal component analysis (PCA) showing relationships among samples. 
skeletal grains include peloids $\left(10 \%_{\mathrm{al}}\right)$ and rare intraclasts, ooids and cortoids. Common multilocular foraminifers $\left(22 \%_{\mathrm{al}}\right)$, moravamminids $\left(16 \%_{\mathrm{al}}\right)$ and moravamminid/ echinoderm hash $\left(11 \%_{\mathrm{al}}\right)$ are accompanied by crinoids, brachiopods, calcispheres, Pachysphaerina sp., trilobites, ostracods, Earlandia sp. and molluscs. Bioclasts are commonly oriented along the bedding planes.

Interpretation: The microfacies was obtained from calciturbidite containing material from higher parts of the carbonate ramp (Fig. 12A). The moravamminids as well as multilocular foraminifers occurred especially in inner- or mid-ramp environments and became rare or absent below the storm wave base (Skompski 1987, Hennebert \& Lees 1991, Adams et al. 1992, Madi et al. 1996, Gallagher 1998, Devuyst \& Lees 2001, Vachard \& Cózar 2010, Vachard et al. 2010). Moravamminids are known to form "thickets" or "meadows" in shallow low- to moderate- energy environments (Skompski 1987, Adams et al. 1992) inhabited by some multilocular foraminifera (see Gallagher 1998).

Microfacies C. - The microfacies (Z1, Z2, Z4a, Z9, Z12, Z10, Z8, Z5; Fig. 3C, G) comes from laminated calcisiltites to fine-grained calcarenites with cherts. These packstones/wackestones contain $65-88 \%$ of micrite/ microsparite, $12-23 \%$ allochems and very rarely small grains of detrital quartz. Allochems are dominated by sponge spicules $\left(11-55 \%{ }_{\mathrm{al}}\right)$, moravamminids $\left(\leq 14 \%_{\mathrm{al}}\right)$, moravamminid/echinoderm hash $\left(\leq 14 \%_{\mathrm{al}}\right)$, small multilocular foraminifers $\left(\leq 12 \% \%_{a 1}\right)$, peloids $\left(\leq 11 \%_{a 1}\right)$ and Pachysphaerina sp. $\left(\leq 8 \% \%_{a 1}\right)$. Trilobites, crinoids, Earlandia sp., brachiopods, ostracods, calcispheres, molluscs and Girvanella sp. are also present. Samples are partly silicified, compacted, and have a banded/smudged appearance with respect to various concentrations of $\mathrm{SiO}_{2}$, seams with insoluble residue and bioclasts orientation. Samples Z6 and Z7 were excluded from analyses due to considerable diagenetic overprint (silicification and compaction), but are close/correspond to those of Group C.

Interpretation: Probably distal calciturbites. Common sponge spicules can be autochthonous or derived from higher parts of the outer ramp environment. Subgroups $\mathrm{C} 1$ and $\mathrm{C} 2$ differ in the number of components derived from shallower environments, such as moravamminids and their hash, multilocular foraminifera, Pachysphaerina or Earlandia. Multilocular foraminifers are represented only by relatively small, and so easily transportable, specimens. Earlandia is supposed to be an epifaunal suspension-feeder (Vachard et al. 2018b) or infaunal detritovore living at the sediment-water interface and adapted to survive in a wide range of subtidal environments, from high-energy environments to low-energy environments below the storm wave base (Gallagher 1998). Background sedimentation included radiolarian mudstone/wackestone (Fig. 12A), which was recorded in the intraclasts at the base of the most prominent calciturbidite bed.

Microfacies D. - The microfacies (Z11; Fig. 3D, H) was obtained from light grey calcisiltite to fine-grained calcarenite in the weathered, trilobite-bearing interval. The wackestones/packstones comprise $74 \%$ micrite/ microsparite and $26 \%$ of allochems. Grains of detrital quartz are small and rare. Determinable bioclasts are dominated by crinoids $\left(21 \%_{\mathrm{al}}\right)$, trilobites $(15 \%$ al $)$, globochaetids $\left(8 \% \%_{\mathrm{al}}\right)$, ostracods $\left(6 \%_{\mathrm{al}}\right)$ and moravamminid/ echinoderm hash $\left(6 \%_{\mathrm{al}}\right)$. Molluscs, calcispheres, sponge spicules, brachiopods, Earlandia sp., Pachysphaerina sp. and conodonts are also present (in addition, bryozoans were observed in insoluble residue). Bioclasts show various degrees of disarticulation and fragmentation. Nonskeletal grains are represented by small peloids $\left(10 \%{ }_{\mathrm{al}}\right)$.

Interpretation: Microfacies D has a specific character, as it lacks or almost lacks the sponge spicules typical of Group C, the ooids of Group A, and the multilocular foraminifers and the moravamminids of Group B, and mainly contains heterotrophs such as crinoids, trilobites and ostracods. According to its allochem composition and the presence of globochaetids, it is similar to some Lower Devonian slope facies from the Barrandian area (Loděnice, Řeporyje, Dvorce-Prokop, Třebotov limestones; see Weinerová et al. 2017, Bábek et al. 2018). Common epibionts observed on silicified material (Fig. 10F) indicate longer resting of skeletal material on the sea floor and slow sedimentation rates. Strong weathering of these beds blurred depositional structures and makes interpretation difficult. The layers may reflect (I) a sea-level lowering and limited input of allochems from shallow settings if the material is "autochthonous", (II) a change in oxygen or nutrient level leading to the suppression of sponges by other fauna, and simultaneous limited input of allochems from shallow settings, if the material is "autochthonous", or (III) the material is most probably allochthonous and derived from the middle or outer parts of the ramp. The presence of articulated trilobites reflects rather shorter transport (Fig. 12A).

Figure 3. Microfacies from the Zetor section. - A - sharp base of calciturbidite bed represented by partly silicified packstone with ooids, peloids, bioclasts, intraclasts and detrital quartz (microfacies A, sample Z4b). $\bullet$ B - packstone of a calciturbidite bed (microfacies B, sample Z3) dominated by multilocular foraminifers, moravamminids, moravamminid/echinoderm hash and peloids, note sparse grains of detrital quartz. $\bullet \mathrm{C}-$ wackestone/ 

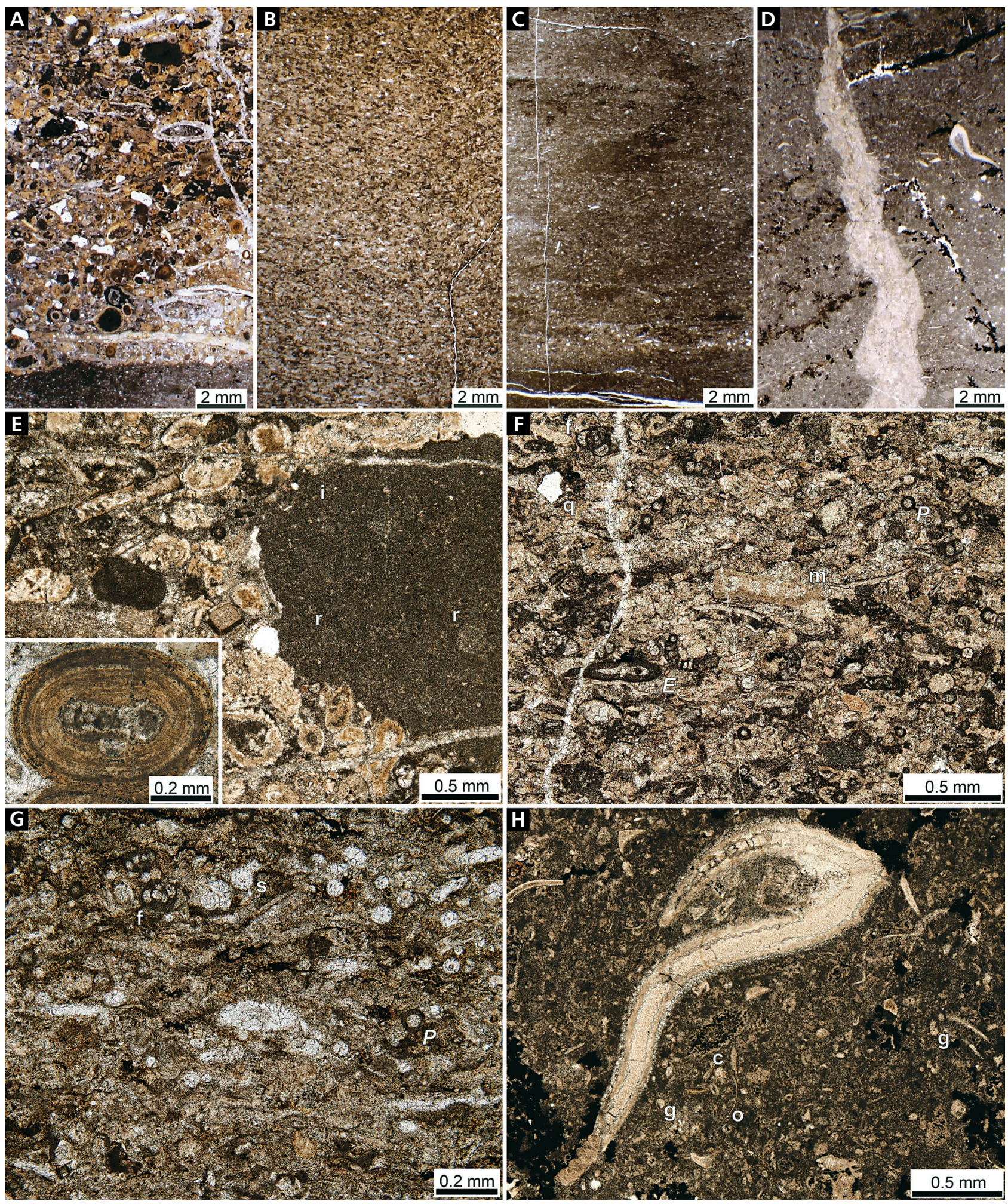

packstone of microfacies $\mathrm{C}$ (sample Z12) with allochems dominated by sponge spicules, moravamminids, moravamminid/echinoderm hash, small multilocular foraminifers, peloids and Pachysphaerina sp. - D - wackestone/packstone of microfacies D (sample Z11) with common crinoids, trilobites, globochaetids and ostracods. $\bullet$ E - detail of microfacies A focused on intraclast (i) represented by mudstone/wackestone with radiolarians (r) and ooid consisting of concentric laminae around nuclei represented by a foraminifer. $\bullet \mathrm{F}-$ detail of microfacies B showing moravamminids (m), multilocular foraminifers (f) Earlandia sp. (E), Pachysphaerina sp. $(P)$ and detrital quartz (q). $\bullet \mathrm{G}$ - detail of microfacies $\mathrm{C}$ showing sponge spicules (s) multilocular foraminifers (f) and Pachysphaerina sp. $(P) \cdot \bullet \mathrm{H}-$ detail of microfacies D focused on trilobite fragment with silicified surface portions and calcareous inner portion, note also crinoids (c), ostracods (o) and globochaetids $(\mathrm{g})$. 
FORAMINIFERS

MFZZONES CONODONTS
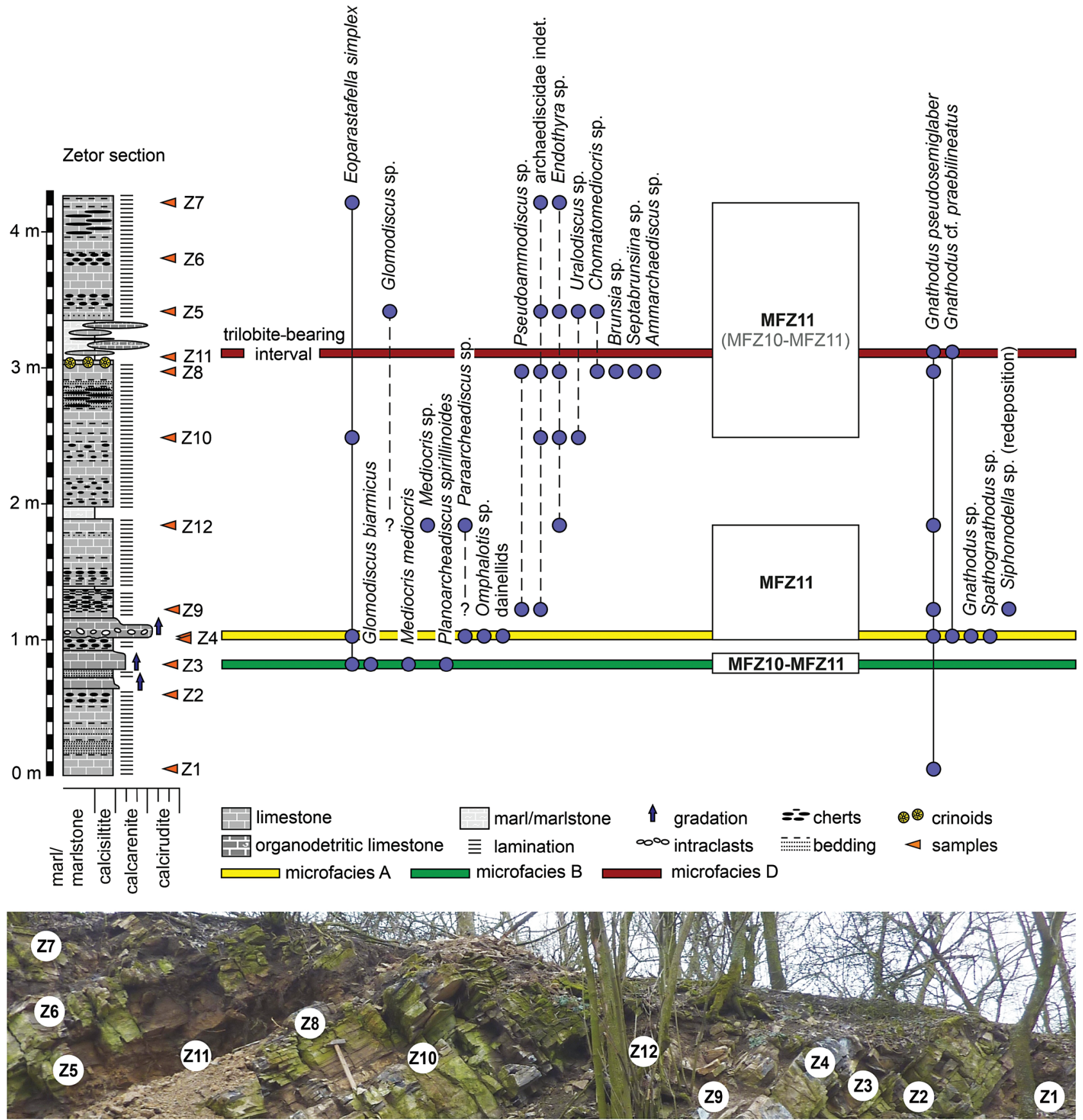

Figure 4. Lithological scheme of the Zetor section with biostratigraphic data and a photograph of this section (sampled beds marked).

\section{Biostratigraphy}

Foraminifers. - The foraminifer zones used here (Fig. 1E) were originally defined by Poty et al. (2006). Foraminifers Planoarchaediscus spirillinoides (Rauzer-Chernousova), Glomodiscus biarmicus Malakhova, Mediocris mediocris (Vissarionova) and Eoparastaffella simplex Vdovenko in sample Z3 from the lower part of the section correspond to the upper part of MFZ10 or to MFZ11A (sensu Poty et al. 2006, Okuyucu et al. 2013, Zandkarimi et al. 2014). The association of the following sample Z4, comprising Eoparastaffella simplex, Paraarchaediscus, dainellids and Omphalotis indicates MFZ 11. This foraminiferal zone continues up to sample Z12. The following samples 
Z10 and Z8 contain rare, very small purely preserved foraminiferal fauna, where the closer determination of archaediscids is often difficult. The associations correspond to MFZ10-11 and a similar association was obtained from samples Z5 and Z7. The presence of MFZ 11 in the lower part of the section (between samples Z4 and Z11) suggests that the upper part of the section (between samples Z10 and Z7) can be also correlated with MFZ11 (Fig. 4). The sample Z11 from the trilobite-bearing interval does not contain multilocular foraminifers but its biostratigraphic interpretation is based on the foraminiferal fauna from the lower part of the section (corresponding to MFZ11) and upper part of the section (corresponding to MFZ10-MFZ11). If applied the principle of superposition and no significant tectonic disturbation can be supposed, the sample Z11 and entire trilobite-bearing interval can be assigned to MFZ11.

Conodonts. - The conodont zones used here (Fig. 1E) follow Herbig (2016). Conodont elements are relatively rare in obtained samples. The most common is Gnathodus pseudosemiglaber Thomson \& Fellows, which is present in various samples across the section (Fig. 4). Gnathodus cf. praebilineatus Belka is also present in some samples. The rare presence of Siphonodella sp. is interpreted a reworking from older strata. Some rare remains of polygnathids were also observed. The recorded taxa correspond most probably to the "Gnathodus" homopunctatus Zone, and are consistent with the lower Viséan age documented by foraminifers.

\section{Systematic palaeontology}

Class Trilobita Walch, 1771

Order Proetida Fortey \& Owens, 1975

Superfamily Aulacopleuroidea Angelin, 1854

Family Aulacopleuridae Angelin, 1854

Subfamily Otarioninae R. Richter \& E. Richter, 1926

\section{Genus Namuropyge R. Richter \& E. Richter, 1939}

Type species. - Namuropyge demaneti R. Richter \& E. Richter, 1939.

\section{?Namuropyge gen. et sp. indet.}

Figure 5A, B

Material. - One fragment of right lateral part of the cephalon (CGS TW554).

Remarks. - This incomplete cephalon measures $\sim 4 \mathrm{~mm}$ (ILA). The rather short spines on the lateral border and orientation of the relatively long and thick librigenal spine

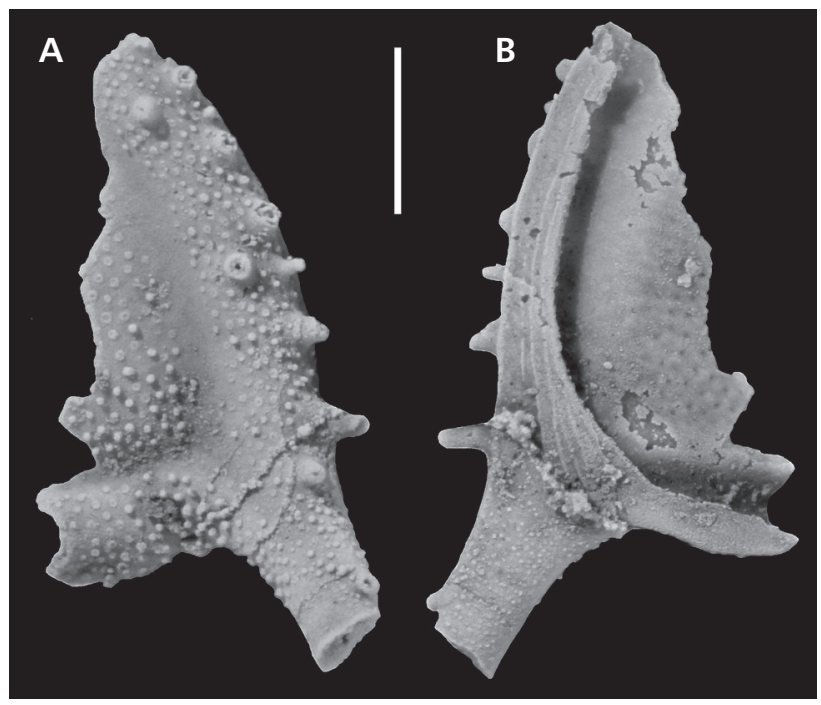

Figure 5. A, B - ?Namuropyge gen. et sp. indet; incomplete cephalon (right lateral portion), CGS TW554; A - dorsal view; B - ventral view. Specimen coated with ammonium chloride. Scale bar: $1 \mathrm{~mm}$.

resemble Namuropyge (Namuropyge) bricta G. Hahn, R. Hahn \& Brauckmann, 1987 and $N$. (N.) nemetona G. Hahn, R. Hahn \& Brauckmann, 1980. The broad and relatively robust lateral and posterior border is more similar to Namuropyge (N.) bricta. Relatively short spines on the lateral border are in both horizontal/subhorizontal and vertical/subvertical directions, which rather resembles $N$. (N.) nemetona (see Böth \& Brauckmann 1979, figs 4, 5; Hahn \& Hahn 1996, p. 187, figs 246, 247).

Superfamily Proetoidea Hawle \& Corda, 1847

Family Phillipsiidae Oehlert, 1886, emend. Hahn et al. (1980)

Subfamily Archegoninae G. Hahn \& Brauckmann, 1984

\section{Genus Liobole R. Richter \& E. Richter, 1949}

\section{Subgenus Liobole (Liobole) R. Richter \& E. Richter, 1949}

Type species. - Phillipsia glabra Holzapfel, 1889.

\section{Liobole (Liobole) cf. trimeroides (Holzapfel, 1889) Figure 6A}

Material. - One cranidium (CGS TW549).

Remarks. - The specimen measures $6.3 \mathrm{~mm}$ (SL). The cuticule of this cranidium is partly weathered and mostly exfoliated. The course of the facial suture and the overall width of fixigenae suggest the affinity with L. (L.) trimeroides (Holzapfel, 1889). This is demonstrated mainly by the rather narrow fixigena near $\varepsilon-\zeta$, and $\zeta$ 
weakly marked to absent. Further similarity is represented by the conical glabella, with three pairs of lateral glabellar furrows on the internal mould. The damage to the cranidium does not allow other features to be observed, for example, the presence/absence of lateral glabellar furrows on the external surface of the glabella and the morphology of the occipital ring [see Müller \& Hahn 2018 for a recent diagnosis of $L$. (L.) trimeroides].

\section{Subgenus Liobole (Panibole) Gröning, 1985, emend. Müller \& Hahn (2018)}

Type species. - Phillipsia subaequalis Holzapfel, 1889.

\author{
Liobole (Panibole) aff. glabroides (R. Richter \& E. \\ Richter, 1949)
}

Figure 6G

\section{Material. - One cranidium (CGS TW548).}

Remarks. - The specimen measures $\sim 9.2 \mathrm{~mm}$ (SL). The cranidium shows very close morphology to $L$. $(P$.) glabroides (R. Richter \& E. Richter, 1949), L. (P.) paraglabroides G. Hahn \& Müller, 2018 and $L$. (P.) obscura Yuan \& Xiang, 1998. The glabella is conical, indistinctively constricted near $\gamma$, with a narrower frontal lobe, which contrasts with the posterior portion. A rather broadly rounded course of facial sutures near $\beta$ is more similar to $L$. (P.) paraglabroides and $L$. (P.) obscura than to L. (P.) glabroides (cf. Müller \& Hahn 2018, Yuan \& Xiang 1998). $\beta$ is placed more adaxially than $\delta$ in the new specimen: in comparison, all three mentioned species have $\beta$ placed more abaxially than $\delta$ (or the $\beta$ takes approximately the same abaxial distance as $\delta$ ), and broader fixigenae near $\beta-\beta$. Relatively long $\beta-\gamma$, as well as $\varepsilon-\zeta$ approximately parallel with the circumaxial furrow are also common features in all three mentioned taxa. The absence of $\varepsilon$ on the right side of the facial suture (left side damaged) on the new specimen is a common feature with $L$. (P.) paraglabroides. The occipital furrow is rather deep and developed only in the central part (tr.) of the median lobe, and it does not reach the circumaxial furrow laterally (tr.) - this feature is closer to $L$. (P.) glabroides than to the remaining two taxa mentioned. A very similar occipital furrow and similarly narrower fixigenae between $\beta-\beta$ are developed in Liobole (Panibole) sp., aff. L. (P.) glabroides depicted by Müller \& Hahn (2018, pl. 4, fig. 9): when compared with the new cranidium (Fig. 6G), the specimen of Müller and Hahn has somewhat larger and more laterally projecting palpebral lobes. Lateral glabellar furrows on the upper surface of the exoskeleton were not observed in the Moravian specimen, which also rather resembles L. (P.) glabroides (Müller \& Hahn 2018).

\section{Liobole (Panibole) aff. testans Chlupáč, 1961 Figure 6B-F}

Material. - Four cranidia (CGS TW542-544, 580), one librigena (CGS TW545 A).

Description. - The cranidia measure between $\sim 3.2 /$ $5.5 \mathrm{~mm}$ (ISL/ESL; CGS TW580) and $9.8 \mathrm{~mm}$ (SL; CGS TW544). The main features can be summarized as follows: Anteriorly narrowing glabella with indistinctive constriction near $\gamma$; glabellar furrows not visible on external surface of the exoskeleton. Fixigenae near $\beta-\beta$ relatively broad (tr.); $\beta$ placed somewhat more adaxially than $\delta$; distinctively laterally expanded palpebral lobes; $\gamma, \delta$ and $\varepsilon$ relatively sharply rounded; straight or almost straight facial suture between $\varepsilon-\zeta$ clearly diverging posteriorly; $\varepsilon-\zeta$ slightly posteriorly divergent with circumaxial furrow; $\zeta$ marked; facial suture around $\zeta$ relatively sharply rounded.

The librigena measures $10 \mathrm{~mm}$ (LA). The course of the facial suture generally corresponds to the cranidia mentioned above. The slightly convex border bears $\sim 3$ relatively long and very narrow terrace ridges on its anterior two thirds. The border furrow is relatively broad and rather shallow. The eye is small (to medium sized).

Remarks. - The morphological features of cranidia show close affinity with the holotype of Liobole (Panibole) testans. There are some minor differences: the drawings of Liobole testans by Chlupáč (1966, p. 64, text-fig. 17) show a very sharply rounded facial suture around $\beta$, but in the new specimens it is rather broadly rounded. The course of the facial suture between $\varepsilon-\zeta-\omega$ is somewhat variable in the cranidia depicted by Chlupáč (1966, textfig. 17, pl. 15, figs 2,3) and it thus cannot be excluded that these specimens represent in fact more than one species. The holotype glabella of $L$. testans shows relatively clearly marked lateral glabellar furrows on the internal

Figure 6. A - Liobole (Liobole) cf. trimeroides (Holzapfel, 1889); cranidium, dorsal view, CGS TW549. • B-F - Liobole (Panibole) aff. testans Chlupáč, 1961; B - librigena, dorsal view, CGS TW545 A; C, D - cranidium, CGS TW542, dorsal view (C) and left lateral view (D ); E - cranidium, dorsal view, CGS TW543; F - incomplete cranidium, dorsal view, CGS TW544. • G - Liobole (Panibole) aff. glabroides (R. Richter \& E. Richter, 1949), cranidium, dorsal view, CGS TW548. - H, I - Liobole (Panibole) sp.; H - incomplete cranidium, dorsal view, CGS TW547; I - cranidium, dorsal view, CGS TW546. - J-M - Liobole sp., various morphotypes of pygidia, all in dorsal view; J - CGS TW577; K - CGS TW571; L - CGS TW576; M - CGS TW572. All specimens coated with ammonium chloride. Scale bars: $2 \mathrm{~mm}$ (all). 

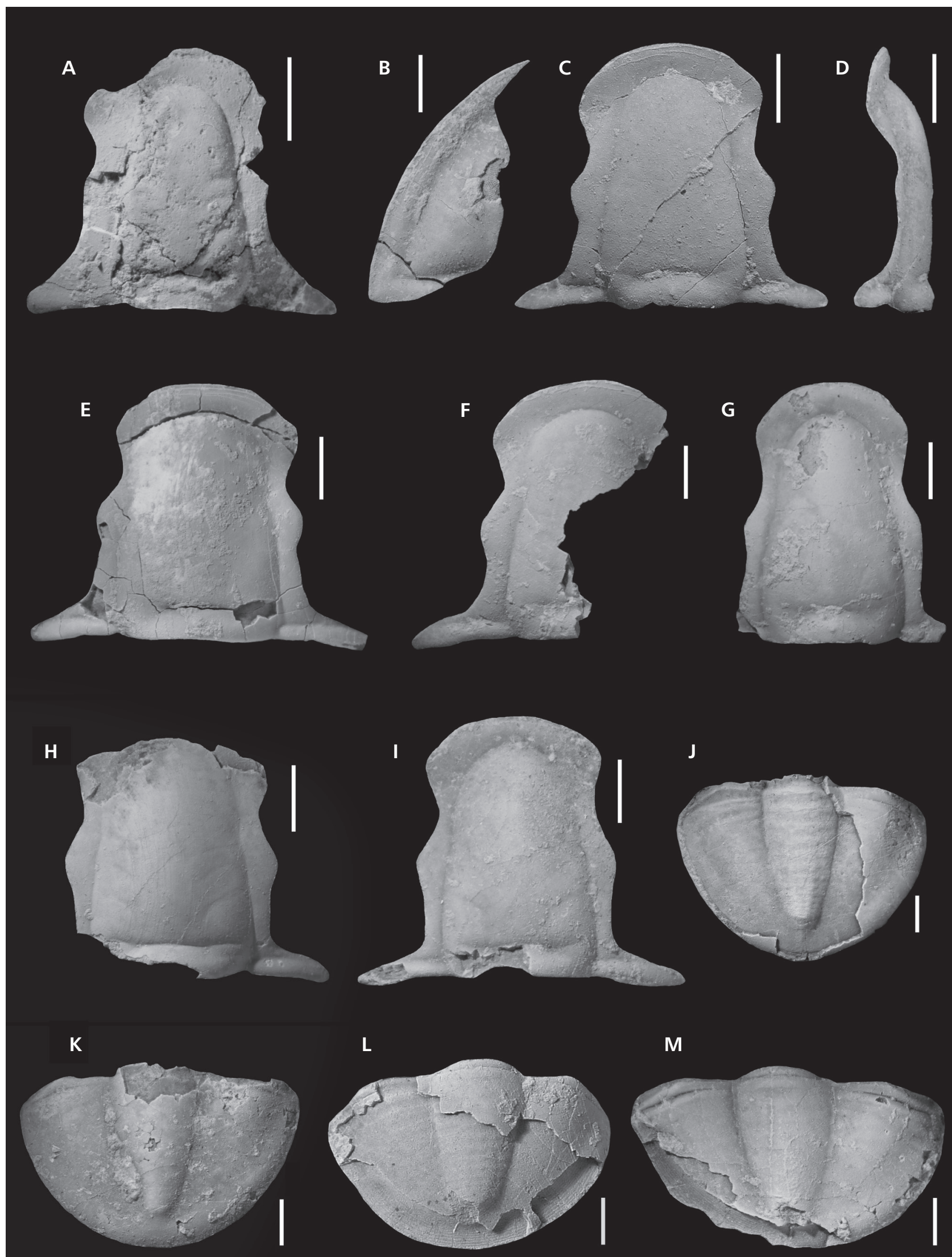
mould. Chlupáč (1966) noted "quite indistinct" glabellar furrows on the external surface of the exoskeleton in L. testans. Gröning (1986, p. 50) noted and depicted $\mathrm{S} 1-\mathrm{S} 3$ in the drawing of the holotype specimen (both on internal and external moulds) of this taxon.

In comparison with various species of Liobole (Panibole) (see Müller \& Hahn 2018, 2019), the assigned librigena (Fig. 6B) shows the eye, which is also approximately the same size as the eye of librigena previously assigned to Liobole testans by Chlupáč (1966, pl. 15, fig. 1).

Some specimens discussed therein were preliminarily determined as Liobole aff. galaxaura (Weiner et al. 2014). The holotype cranidium of $L$. (P.) galaxaura G. Hahn, R. Hahn \& Müller, 1996 (Hahn et al. 1996, Müller \& Hahn 2018) slightly differs in following features: $\varepsilon-\zeta$ approximately parallel with circumaxial furrow, fixigenae between $\varepsilon-\zeta$ roughly parallel or indistinctively divergent posteriorly, slightly less laterally expanded palpebral lobes. On the other hand, another cranidium previously assigned to $L$. $(P$.) galaxaura shows a slightly more posteriorly divergent course of $\varepsilon-\zeta$ (Hahn et al. 1996, pl. 2, fig. 10) and slightly broader fixigenae near $\varepsilon-\zeta$, which also resemble $L$. testans and new specimens in this feature. The absence of glabellar furrows on the outer surface of the exoskeleton in L. (P.) galaxaura (Müller $\&$ Hahn 2018) is a common feature in Moravian cranidia from the Zetor section. L. (P.) galaxaura has a somewhat larger eye (Müller \& Hahn 2018) than librigena (Fig. 6B) from the Zetor section.

\section{Liobole (Panibole) sp.}

Figure 6H, I

Material. - Two cranidia (CGS TW546, 547).

Remarks. - The cranidia measure $7.3 / 8.2 \mathrm{~mm}$ (ISL/ESL; CGS TW547) and $~ 8.3 \mathrm{~mm}$ (SL; CGS TW546). Both cranidia are similar to several taxa of Liobole (Panibole): L. (P.) jugovensis (Osmólska, 1968), L. (P.) valtejana Gandl, 1977, L. (P.) prisca (Gandl, 1977), L. (P.) gandli Gröning, 1985, L. (P.) isis Müller \& G. Hahn, 2018, and L. (P.) groeningae Müller \& G. Hahn, 2018. The main features in common with these taxa include: conical glabella with slight or indistinctive constriction near $\gamma$, relatively broad $\beta-\beta, \beta$ placed somewhat more adaxially than $\delta$, similar morphology and relative length (exsag.) of palpebral lobe, relatively narrow fixigenae near $\varepsilon-\zeta$, $\varepsilon-\zeta$ roughly parallel, and $\varepsilon-\zeta$ approximately parallel with circumaxial furrow.

The following further similarities and differences between Moravian specimens and the above mentioned taxa might be discussed: 1) the new specimens slightly differ in the parallel to slightly posteriorly convergent course of facial sutures between $\varepsilon-\zeta$. The above mentioned taxa have $\varepsilon-\zeta$ in a relatively parallel to posteriorly slightly divergent course. 2) S1-S3 are visible on the external surface of the exoskeleton in Moravian specimens (rather weakly marked, depending on illumination). Some of the noted species have at least S1 or more lateral glabellar furrows visible on the external surface of exoskeleton $[L$. (P.) jugovensis, L. (P.) valtejana, L. (P.) prisca]. A smooth external surface of the glabella, without visible lateral glabellar furrows, was described in other species $[L .(P$.$) gandli, L. (P$.$) groeningae ]$ or the external surface of the glabella is generally unknown $[L$. (P.) isis $]$. 3) The width of the fixigena between $\varepsilon-\zeta$ in both new specimens seems to be more similar to $L$. (P.) gandli, L. (P.) valtejana, L. (P.) isis and $L$. (P.) groeningae, whereas $L$. (P.) jugovensis and $L$. (P.) prisca have slightly broader fixigenae near $\varepsilon-\zeta$.

It should be noted that a relatively low number of wellpreserved cranidia was used for the description of several related species (Osmólska 1968, Gandl 1977, Gröning 1986, Müller \& Hahn 2018), and in some cases only one specimen was available $[L .(P$.$) gandli, L .(P$.$) isis]. The$ intraspecific variability is thus relatively poorly known, which complicates further comparisons.

\section{Liobole sp.}

Figure $6 \mathrm{~J}-\mathrm{M}$

Material. - 14 variously complete/damaged holaspid pygidia (CGS TW520 B, $521 \mathrm{~B}, 532 \mathrm{~B}, 558 \mathrm{C}, 571,572$, 574-579, 581-583 A), one librigena (CGS TW531 B).

Remarks. - The pygidia measure between $\sim 3.0 / 3.9 \mathrm{~mm}$ (ISL/ESL; CGS TW579) and $\sim 12.3 \mathrm{~mm}$ (SL; CGS TW581). At least four taxa of Liobole seem to be present according to cranidia (see above). Potentially associated pygidia are represented by similar morphotypes, which differ mainly in width/length ratio ( $\mathrm{W} / \mathrm{L}=1.3-1.7)$, and further differences such as the width of axis are relatively minor. Various similar pygidia are present in Liobole (Panibole) galaxaura, L. (P.) glabroides, L. (P.) paraglabroides, $L$. (P.) testans, Liobole (L.) trimeroides and also in other Liobole taxa (Chlupáč 1966, Gandl, 1977, Gröning 1986, Müller \& Hahn 2018). It is currently not clear whether the recorded pygidia represent intraspecific variability or two or more taxa. Additional material, and ultimately articulated specimens, will be necessary because the differences are relatively minor. The correlation with cephalic parts of Liobole discussed above is problematic.

The librigena measures $1.4 \mathrm{~mm}$ (LA). The damaged course of facial suture and partly exfoliated state of preservation do not allow the clear assignment to the above discussed cranidia. 
Genus Angustibole G. Hahn, 1965

Type species. - Archegonus (Angustibole) winterbergensis G. Hahn, 1965.

Angustibole aff. winterbergensis G. Hahn, 1965

Figure $7 \mathrm{~A}-\mathrm{E}$

Material. - Three cranidia (CGS TW555-557).

Remarks. - The specimens measure $\sim 2.8 \mathrm{~mm}$ (SL; CGS TW556) to $\sim 5.3 \mathrm{~mm}$ (SL; CGS TW555). The three cranidia, probably belonging to the same species, show close morphology with Erdbachaspis Müller \& G. Hahn, 2018 and Angustibole (Hahn 1965, 1966; Müller \& Hahn 2018). As summarised by Müller \& Hahn (2018), the main differences between both genera include: broader (tr.) fixigenae near $\beta-\beta$ in Erdbachaspis; the weakly separated frontal lobe of the glabella in Erdbachaspis $v s$ a relatively clearly separated frontal lobe of glabella in Angustibole; and very short or rudimentary genal spines in Erdbachaspis vs relatively long genal spines in Angustibole. Two smaller cranidia (Fig. 7A-D) show generally very similar morphology with similarly sized specimens of Angustibole winterbergensis of Hahn (1966, pl. 47, figs 12, 13), and the slightly coarser surface granulation on the glabella of both Moravian specimens is a minor difference. The cranidium depicted in the Fig. 7A is morphologically very close to the specimen depicted in Fig. 7D but the latter differs in a slightly narrower (tr.) fixigenae near $\beta-\beta$. The separation of the frontal lobe of the glabella is comparable in both cranidia rather with similarly-sized specimens assigned to Angustibole winterbergensis, than larger specimens of Erdbachaspis (cf. Hahn 1966, Müller \& Hahn 2018) although the differences are rather subtle. The third, somewhat larger cranidium (Fig. 7E) is partly damaged. This specimen was preliminarily determined as Proliobole cf. nitida holzapfeli (Weiner et al. 2014) (Proliobole is a younger synonym of Cyrtoproetus according to Müller \& Hahn 2018) but is here reassigned because of the relatively short portion of $\varepsilon-\zeta$ and larger palpebral lobe, extending further backwards (sag.) which is not similar to Cyrtoproetus holzapfeli and the specimen is also similar to smaller cranidia (Fig. 7A-D). The damage to this specimen (Fig. 7E) complicates observations of the separation of the frontal glabellar lobe, which seems to be rather clearly separated. However, the specimen is slightly broader than holotype of $A$. winterbergensis (Hahn 1966, pl. 47, fig. 11; Müller \& Hahn 2018, pl. 10, fig. 6). The damaged palpebral lobe seems to be relatively large, probably slightly larger and more laterally extended (tr.) than in various species of Erdbachaspis [E. granulifera (Holzapfel, 1889), E. aithyia (G. Hahn, R. Hahn \& Müller,
2001), E. bathapoikos (G. Hahn, R. Hahn \& Müller, 1998), see Müller \& Hahn 2018].

\section{Genus Cyrtoproetus Reed, 1943}

Type species. - Phillipsia cracoensis Reed, 1899.

\section{?Cyrtoproetus sp. 1}

Figure $7 \mathrm{H}$

Material. - One incomplete pygidium (CGS TW560).

Remarks. - The pygidium measures $\sim 5.5 \mathrm{~mm}$ (SL). The specimen studied shows a generally very similar morphology (similar number of ribs partly entering the border, similar width of axis and number of axial rings) to the pygidium depicted by Hahn (1966, pl. 46, fig. 7, specimen "SMF 17903") which they determined as Archegonus (Phillibole) nitidus (Holzapfel, 1889) and considered as conspecific with Phillipsia nitida described by Holzapfel (1889). The specimen (Fig. $7 \mathrm{H}$ ) only indistinctively differs by slightly coarser granules on the axial rings. Gröning (1986) followed the determination of the specimen "SMF 17903" at a specific level and assigned it to Proliobole; this assignment was also followed by Hahn et al. (2003). Proliobole was subsequently synonymised with Cyrtoproetus by Müller $\&$ Hahn (2018). However, Archegonus (Phillibole) nitidus in Hahn (1966) was only partly and tentatively listed as a synonym of Cyrtoproetus nitidus (Holzapfel, 1889) by Müller \& Hahn (2018). Moreover, Müller \& Hahn (2018, p. 52) considered the pygidia of Archegonus (Phillibole) nitidus depicted by Hahn (1966, pl. 46, figs 4-8) as belonging to various taxa (without closer determination). The pygidia assigned to Cyrtoproetus nitidus by Müller \& Hahn (2018) have a very low number of clearly marked ribs (two) and do not resemble the new specimen (Fig. $7 \mathrm{H}$ ) in this feature. A pygidium with similar morphology of ribs partly entering the border is also known in Cyrtosymbole (Macrobole) drewerensis of R. Richter \& E. Richter (1951, pl. 1, fig. 11).

\section{?Cyrtoproetus sp. 2}

Figure 7I

Material. - One incomplete pygidium (CGS TW585).

Remarks. - The pygidium measures $\sim 4.6 \mathrm{~mm}$ (SL). This specimen has a relatively long axis, reaching, or almost reaching, a weakly separated border, about $8+1$ or $9+1$ axial rings, four marked ribs and a surface covered by fine granulation. Similar pygidia are present in Cyrtoproetus (Müller \& Hahn 2018, 2019). For example, Cyrtoproetus holzapfeli (Müller, 2004), C. galapagos Müller \& G. Hahn, 
2018 and C. roesenbeckensis Müller \& G. Hahn, 2019 have similar granulation and morphology of ribs and number of ribs. The closer determination of the new specimen is complicated because of unknown cephalic parts.

\section{?Archegoninae, genus et species indet. 1}

Figure 7F

Material. - One damaged pygidium (CGS TW558 A).

Remarks. - The small damaged pygidium measures $\sim 1.9 \mathrm{~mm}$ (SL). The specimen demonstrates the following similar features to some archegonine species of Erdbachaspis [Erdbachaspis sp., aff. E. richteri - see Müller \& Hahn 2019, pl. 5, fig. 8; E. granulifera: Waribole (Waribole) granulifera in Hahn et al. 1996, pl. 3, fig. 14] and Angustibole winterbergensis (Hahn 1966, pl. 47, fig. 15): pygidium rather flat with relatively broad and relatively short axis, broad border and low number of defined rib pairs. Similar features are also known in bollandiine species Carbonoproetus volturnus Müller \& Hahn, 2019 (Müller \& Hahn 2019, pl. 7, figs 4, 5) but this species has the pygidium somewhat more highly vaulted. In comparison with these taxa, the new pygidium slightly differs in that the interpleural furrows are not defined, and only pleural furrows are clearly visible. The specimen and above mentioned cranidia determined as Angustibole aff. winterbergensis bear similar granulation. The assignment of the pygidium to these cranidia is possible but not certain.

\section{?Archegoninae, genus et species indet. 2}

Figure $7 \mathrm{G}$

Material. - One damaged juvenile librigena (CGS TW559).

Remarks. - The specimen measures $\sim 2.0 \mathrm{~mm}$ (ILA). The juvenile librigena (Fig. 7G) has a short librigenal spine, upraised lateral border bearing 3 terrace ridges, relatively large eye (broken off), and bears granulation on the librigenal field. Similar granulation is present in the cranidia of Angustibole aff. winterbergensis described above. The attribution of this librigena to these cranidia is possible but not certain. The similar but larger librigenae known in several species of Erdbachaspis show slightly shorter and less robust to rudimentary librigenal spines (see Müller \& Hahn 2018) than the specimen presented here but the relatively short librigenal spine is more similar to Erdbachaspis than to Angustibole winterbergensis. On the other hand, we can not completely exclude that librigena might belong to the cranidium with features closer to Angustibole. The librigena might also belong to other genera, such as Cyrtoproetus.
?Archegoninae, genus et species indet. 3

Figure 7J

Material. - One pygidium (CGS TW569).

Remarks. - The specimen measures $\sim 3.8 \mathrm{~mm}$ (SL). The morphology of ribs, as well as absent/not clearly defined border, is similar to various representatives of Archegoninae. The somewhat shorter axis considerably narrowing backwards resembles, for example, Archegonus (Phillibole) crameri R. Hahn, 1967 and the border is also not clearly defined in this species (see Hahn 1968, Archinal 1992). Crassibole acrops G. Hahn, R. Hahn \& Becker, 2012 [see Cyrtoproetus (Crassibole) acrops in Hahn et al. 2012] has a similar outline, generally very similar morphology and number of ribs, similar length of axis and number of axial rings, and it differs mainly in having a relatively weakly defined border and probably indistinctively lower width/length ratio of the pygidium. The pygidium assigned to Proliobole podarge by Hahn et al. (1998, pl. 3, fig. 5) is probably the most similar to the new specimen, especially in the following features: overall outline, the morphology and number of ribs, border not (clearly) defined, and similar proportion of axis with a similar number of rings. The specimen depicted by Hahn et al. (1998, pl. 3, fig. 5) has only an indistinctively longer axis.

\section{?Archegoninae, genus et species indet. 4}

Figure $7 \mathrm{~K}, \mathrm{~L}$

Material. - One small fragmentary cranidium (CGS TW567).

Remarks. - The specimen measures $\sim 1.3 \mathrm{~mm}$ (ILA). The preserved anterior part of the cranidium shows the conical anterior part of the glabella, broken and relatively large palpebral lobes, very broad fixigenae between $\beta-\beta$ and conspicuous forward-oriented tip in the central part of the anterior margin of the upraised subtriangular border. A similar morphology of the anterior part of the cranidium is known in Archegonus (A.) aequalis (H. v. Meyer, 1831) (see Hahn 1968). A similar upraised anterior border with tip is also known in Brevibole brevispina brevispina (Osmólska, 1962) (Osmólska 1962, Archinal 1992, Hahn et al. 1996, Müller \& Hahn 2018) and in Lichanocoryphe cephalispina (Prentice, 1967) and L. kozlowskii (Osmólska, 1962) (Osmólska 1962, Prentice 1967, Hahn \& Wunn-Petry 1983, Hahn et al. 1994, Owens \& Tilsley 1995, Hahn \& Hahn 2002).

?Archegoninae, genus et species indet. 5

Figure $7 \mathrm{M}, \mathrm{N}$

Material. - Two incomplete pygidia (CGS TW568, 570). 


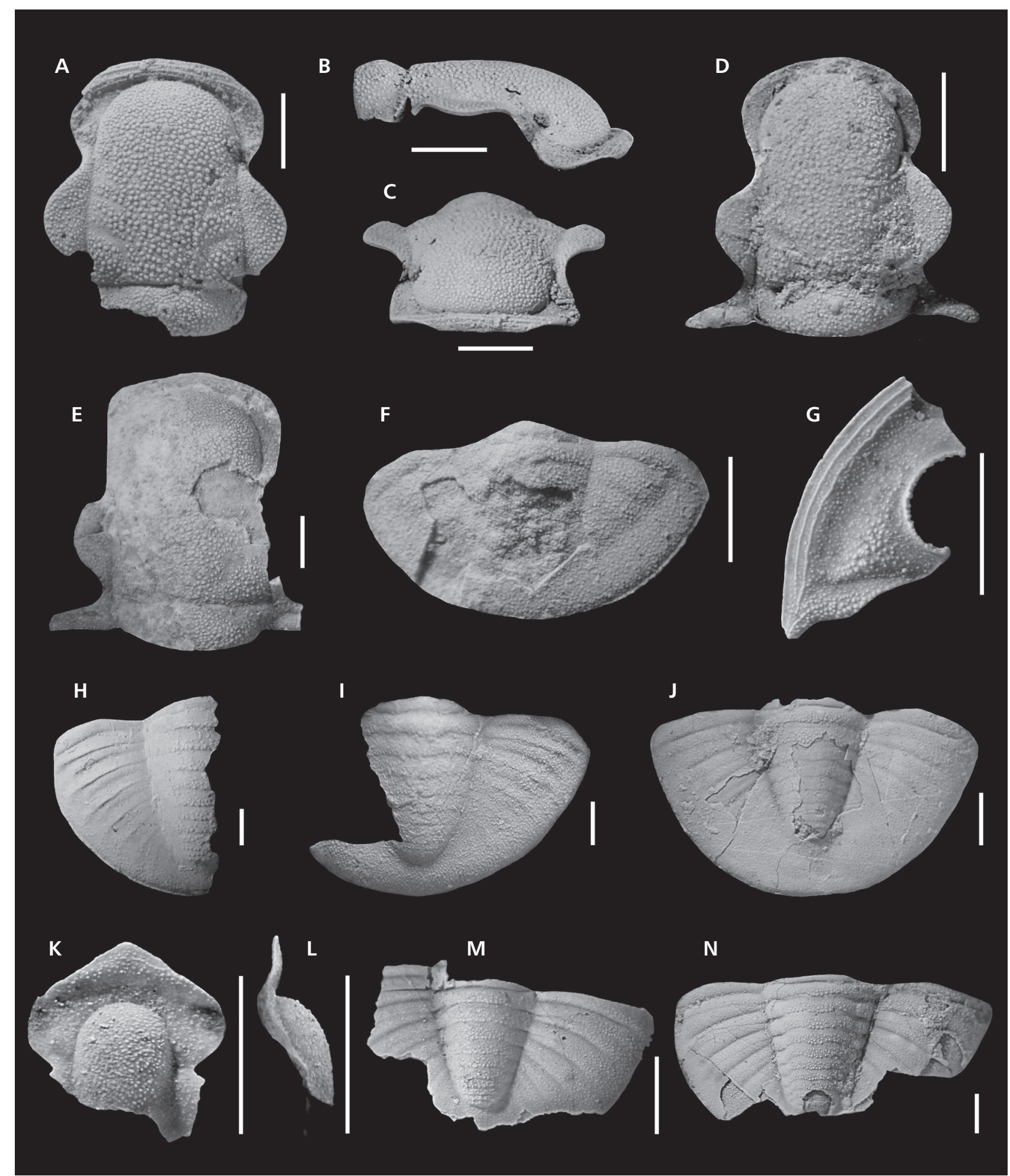

Figure 7. A-E - Angustibole aff. winterbergensis (G. Hahn, 1965); A-C - incomplete cranidium, CGS TW557, dorsal view (A), right lateral view (B), anterior view (C); D - cranidium, dorsal view, CGS TW556; E - damaged cranidium, dorsal view, CGS TW555. $-\mathrm{F}$ - ?Archegoninae, genus et species indet. 1; damaged pygidium, dorsal view, CGS TW558 A. $\bullet \mathrm{G}-$ ?Archegoninae, genus et species indet. 2; damaged librigena, dorsal view, CGS TW559. $・ \mathrm{H}-$ ? Cyrtoproetus sp. 1; incomplete pygidium, dorsal view, CGS TW560. • I - ?Cyrtoproetus sp. 2; incomplete pygidium, dorsal view, CGS TW585. • J - ? Archegoninae, genus et species indet. 3; pygidium, dorsal view, CGS TW569. $\bullet$ K, L - ?Archegoninae, genus et species indet. 4; incomplete cranidium, CGS TW567, dorsal view (K), left lateral view (L). $\bullet$ M-N - ?Archegoninae, genus et species indet. 5; M - incomplete pygidium, dorsal view, CGS TW568; N - incomplete pygidium, dorsal view, CGS TW570. All specimens coated with ammonium chloride. Scale bars: $1 \mathrm{~mm}$ (all). 
Remarks. - The specimens measure $\sim 3.7 \mathrm{~mm}$ (ILA; CGS TW568) and $\sim 8.1 \mathrm{~mm}$ (ILA; CGS TW570). Two pygidia probably belonging to the same species are tentatively assigned to Archegoninae. Very similarly marked ribs and a similar number of axial rings resemble the pygidium of Hahn et al. (1996, pl. 3, fig. 9a) which they assigned to Proliobole krambergensis G. Hahn, R. Hahn \& Müller, 1996. However, Müller \& Hahn (2018) did not consider this pygidum as belonging to Proliobole krambergensis and they tentatively assigned this species to Erdbachaspis. The pygidia of Hahn et al. (1996, pl. 3, figs 8-10) were tentatively assigned to Brevibole halszkae Müller \& G. Hahn, 2018 by Müller \& Hahn (2018).

Subfamily Weaniinae Owens, 1983

\section{Genus Gitarra Gandl, 1968}

Type species. - Griffithides pupuloides Leyh, 1897.

\section{Gitarra cf. gitarraeformis Gandl, 1977}

Figure $8 \mathrm{~A}-\mathrm{E}$

Material. - Two almost complete damaged specimens (CGS TW536, 537), four pygidia (CGS TW501 C; 538a, b; 539a, b; 584), one librigena (CGS TW540), one cranidium fragment (CGS TW541), one damaged hypostoma (CGS TW586).

Description. - Measurements: almost complete specimens: $\sim 15.3 \mathrm{~mm}$ (SL in slightly disarticulated state, CGS TW536) and $\sim 11.9 \mathrm{~mm}$ (SL in slightly disarticulated state, CGS TW537); cranidium fragment $\sim 2.3 \mathrm{~mm}$ (ILA); librigena: $\sim 15.1 \mathrm{~mm}$ (ILA), damaged hypostoma: $\sim 6.3 \mathrm{~mm}$ (SL); pygidia: $\sim 6.2 \mathrm{~mm}$ (SL; CGS TW538a, b) to $\sim 9.8 \mathrm{~mm}$ (SL; CGS TW539a, b).

Remarks. - Owens (2000) considered the Irish specimens of "Phillipsia colei" of Woodward (1883) as conspecific and stratigraphically coeval (upper Chadian/Lower Viséan) with the Spanish G. gitarraeformis of Gandl (1977). The complete or nearly complete specimens of G. gitarraeformis from England depicted by Lawrence \& Stammers (2014) were considered to be Namurian by these authors. Kennedy \& Stammers (2018) depicted further English specimens of G. gitarraeformis which they considered as Viséan (Chadian).

The almost complete Moravian specimen (Fig. 8A) bears nine thoracic segments, as specimens from England and Ireland (Osmólska 1970: "Weania colei", Owens 2000, Lawrence \& Stammers 2014, Kennedy \& Stammers 2018) and complete specimens from Spain were not published. In the second almost complete Moravian specimen (Fig. 8B) the anterior two thoracic segments seem to be covered by slightly disarticulated cephalic parts. There are no major differences in comparison with the type specimens of Gandl (1977). In comparison with the type cranidia depicted by Gandl (1977), specimens from the Zetor section have slightly less constricted glabella near $\gamma$ and an indistinctively narrower frontal lobe of glabella, but these features seem to be somewhat variable in published Irish and British specimens (see Osmólska 1970, pl. 1, fig. 13, "Weania colei”; Gandl 1977; Owens 2000; Lawrence \& Stammers 2014; Kennedy \& Stammers 2018), and might represent intraspecific variability. The glabellar furrows are not observable in almost complete specimens (probably because of damage and weathering), but are clearly developed in fragmented cranidium (Fig. 8E) which resembles the specimen figured by Gandl (1977, pl. 6, fig. 103). The large librigena (Fig. 8C) is almost identical with the specimen of Gandl (1977, pl. 6, fig. 104) but it slightly differs in the course of the facial sutures, suggesting a slightly narrower fixigena near $\beta$. The British and Irish pygidia often seem to have a slightly narrower border with relatively sharp break in slope whereas Moravian specimens seem to have a slightly more broadly vaulted border. The assignment of Moravian specimens to G. gitarraeformis is probable, but it is complicated by the missing revision of the species and detailed published comparison of Spanish, British and Irish specimens. The pygidium of Phillipsia (?) acuticostata figured by Weber (1937, pl. 7, fig. 8) also shows a relatively close morphology with Moravian specimens. The damaged hypostoma shows close similarity to the hypostoma depicted by Owens (2000, fig. 9c), which was preserved with articulated specimen assigned to Gitarra gitarraeformis in the same piece of rock.

Figure 8. A-E - Gitarra cf. gitarraeformis Gandl, 1977; A - damaged almost complete and slightly disarticulated specimen, dorsal view, CGS TW537; B - damaged complete and slightly disarticulated specimen, dorsal view, CGS TW536; C - damaged librigena, dorsal view, CGS TW540; D - damaged hypostoma, ventral view, CGS TW586; E - cranidium fragment, dorsal view, CGS TW541. • F, G - Winterbergia sp.; F - pygidium, negative/prevalently external mould, dorsal view, CGS TW550; G - damaged pygidium, dorsal view, CGS TW551. $\bullet$ - Pseudowaribole (Geigibole) aff. cuetonis Gandl, 1987; damaged cranidium, dorsal view, CGS TW561. • I - Pseudowaribole (Geigibole) aff. sobiae Gandl, 1977, damaged cranidium, dorsal view, GCS TW562. • J - ?Pseudowaribole sp.; damaged librigena, dorsal view, CGS TW563. $\mathrm{K}-\mathrm{M}-$ ?Weaniinae, genus et species indet. 1; K - incomplete pygidium, dorsal view, CGS TW565; L, M - incomplete pygidium, dorsal view, the same specimen variously illuminated, CGS TW564. • N - ? Weaniiane, genus et species indet. 2; fragmentary cranidium, dorsal view, CGS TW552. $\bullet$ O - subfamilia, genus et species indet.; damaged cranidium, dorsal view, CGS TW566. All specimens coated with ammonium chloride. Scale bars: 2 mm (A-D, F, G, N); 1 mm (E, H-M, O). 


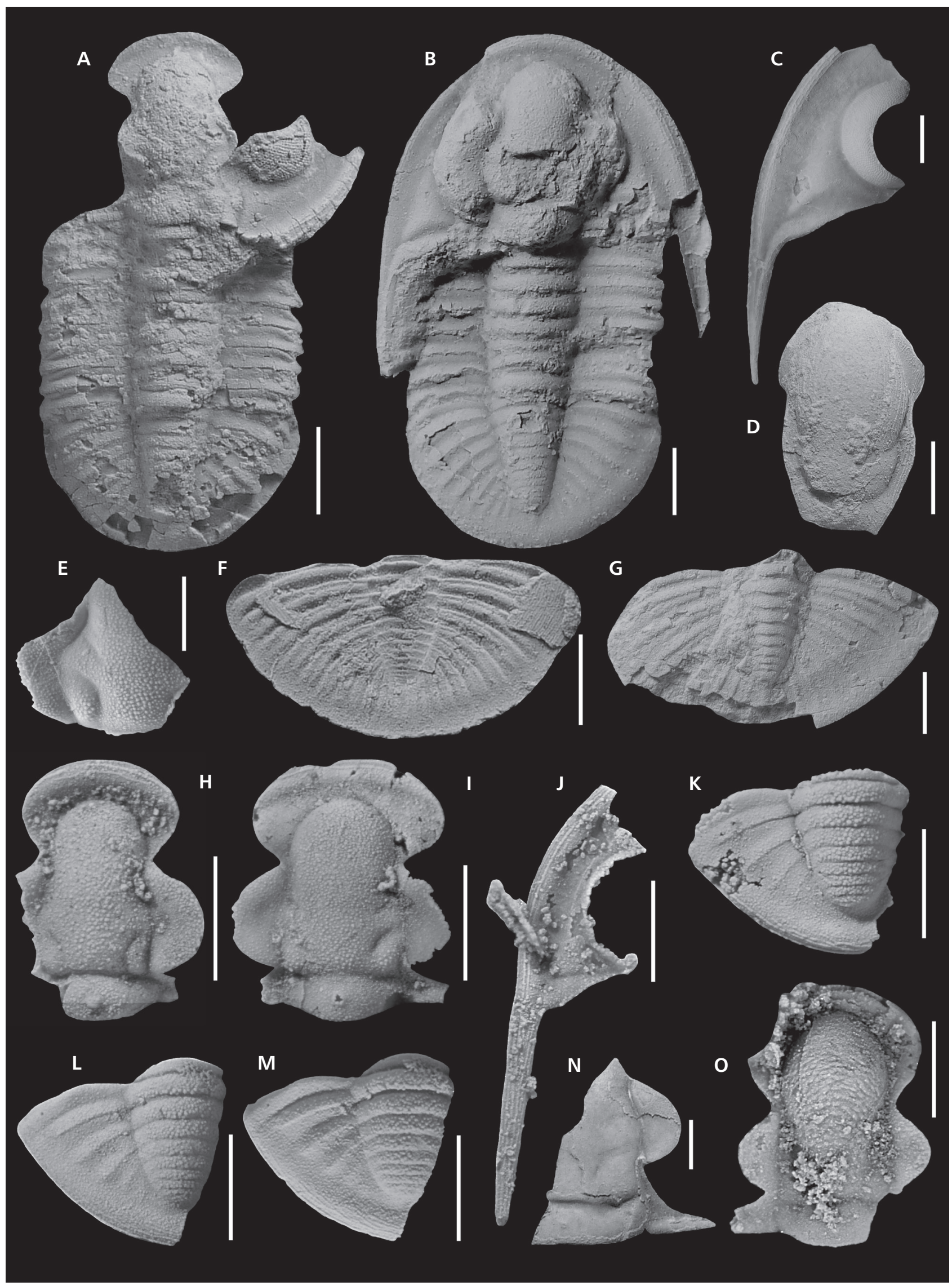


Genus Winterbergia G. Hahn \& Brauckmann, 1975

Type species. - Carbonocoryphe hercynica G. Hahn, 1967.

\section{Winterbergia sp.}

Figure 8F, G

Material. - Three pygidia (CGS TW550, 551, 553), damaged and weathered librigena (CGS TW583 B).

Remarks. - The pygidia measure between $\sim 1.8 \mathrm{~mm}$ (SL; CGS TW553) and $\sim 5.3 / 5.8 \mathrm{~mm}$ (ISL/ESL; CGS TW551). These specimens are very close to that of Winterbergia parahahnorum (Müller, 2007) and Winterbergia egregia (Chlupáč, 1966). This is demonstrated in the identical morphology of approximately ten ribs, a similar number of axial rings, approximately the same length of relatively narrow axis and a relatively broad border. The overall outline of pygidia is very similar to that of Winterbergia parahahnorum and this feature cannot be sufficiently observed in the incomplete pygidia of Winterbergia egregia of Chlupáč (1966). Some differences might be observed in the number of axial rings in pygidia from the Zetor section: specimens with $9+1$ (Fig. 8G), $10+1$ and $12-13+1$ (Fig. 8 F) axial rings were recorded. Subtle differences of variously sized specimens might reflect ontogeny.

The librigena measures $\sim 16.3 / 18.0 \mathrm{~mm}$ (ISL/ESL). The specimen is damaged which complicates closer comparison. The outline of this librigena resembles both above mentioned species of Winterbergia.

\section{Genus Pseudowaribole G. Hahn \& R. Hahn, 1967}

Type species. - Cyrtosymbole (Waribole) octofera R. Richter \& E. Richter, 1926.

\section{Subgenus Pseudowaribole (Geigibole) Gandl, 1968}

Type species. - Cyrtosymbole (Geigibole) geigensis Gandl, 1968.

\section{Pseudowaribole (Geigibole) aff. cuetonis Gandl, 1987}

Figure $8 \mathrm{H}$

Material. - One cranidium (CGS TW561).

Remarks. - The specimen measures $\sim 2.1 \mathrm{~mm}$ (SL). The cranidium shows close morphology with Pseudowaribole (Geigibole) cuetonis Gandl, 1987 in the most features, however, it slightly differs by having only S1 marked (S2 not observed) and in a slightly broader (sag.) praeglabellar area and anterior border.

\section{Pseudowaribole (Geigibole) aff. sobiae Gandl, 1977} Figure 8I

Material. - One cranidium (CGS TW562).

Remarks. - The cranidium measures $\sim 2.3 \mathrm{~mm}$ (SL). This specimen is similar in size to the cranidium of Pseudowaribole (Geigibole) aff. cuetonis (Fig. 8H), and it mainly differs in the considerably broader fixigenae between $\beta-\beta$ and by having S2 marked. The specimen is very close to Pseudowaribole (Geigibole) sobiae (see Gandl 1977) - in comparison with this species, the specimen differs by having a slightly more broadly rounded facial suture around $\beta$.

\section{?Pseudowaribole sp.}

Figure 8J

Material. - One damaged librigena (CGS TW563).

Remarks. - The specimen measures $\sim 4.5 \mathrm{~mm}$ (LA). The librigena is characterised by a long relatively tubular rather than flat librigenal spine and large eye (broken). The librigenal spine and raised lateral border bear several terrace ridges. An indistinct, narrow ridge near the eye is present. Relatively similar librigenae with long librigenal spine are present in some species of Pseudowaribole, such as Ps. (Geigibole) thomasi Brauckmann, 1974, Ps. (Dushania) heisingi G. Hahn \& Brauckmann, 1988a, or Ps. (Geigibole) steedenensis G. Hahn, R. Hahn \& Müller, 1998, the latter species with tubular librigenal spines (Brauckmann 1978, Hahn \& Brauckmann 1988a, Hahn et al. 1998). It cannot be excluded that this librigena belongs to Ps. (Geigibole) aff. sobiae or Ps. (Geigibole) aff. cuetonis described above.

\section{?Weaniinae, genus et species indet. 1}

Figure $8 \mathrm{~K}-\mathrm{M}$

Material. - Two incomplete small pygidia (CGS TW564, $565)$.

Remarks. - The pygidia measure $\sim 1.7 \mathrm{~mm}$ (SL; CGS TW565) and $\sim 1.8 \mathrm{~mm}$ (SL; CGS TW564). Close morphology with Combewoodia ruethenensis (G. Hahn \& R. Hahn, 1969) (Hahn \& Hahn 1969, Müller \& Hahn 2018 ) is demonstrated by a similar outline, number of axial rings and number/morphology of ribs. The axial rings are covered by relatively fine granulation. Contrary to $C$. ruethenensis, these Moravian specimens have a slightly broader pygidial border which bears several terrace ridges. On the other hand, pygidia with relatively similar outline, ribs and number of axial rings were previously also recorded in Pseudowaribole (G.) thomasi Brauckmann, 1974 (Brauckmann 1973, 1974, 1978) and 
it is thus reasonable to expect that these specimens might belong to the subfamily Weaniinae, possibly to $P S$. aff. sobiae or Ps. aff. cuetonis discussed above.

\section{?Weaniiane, genus et species indet. 2} Figure $8 \mathrm{~N}$

Material. - One fragment of large cranidium (CGS TW552).

Remarks. - The specimen measures $\sim 8.3 \mathrm{~mm}$ (ILA). The incomplete cranidium differs from the above mentioned species Winterbergia parahahnorum and Winterbergia egregia especially in the laterally more expanded and larger palpebral lobe - the overall morphology of this specimen shows close affinity with Winterbergia kelanio G. Hahn, R. Hahn \& Müller, 1998 (Hahn et al. 1998, pl. 7, fig. 11). The specimen slightly differs from $W$. kelaino especially in the lack of sharply marked $\zeta$ and slightly more posteriorly diverging $\varepsilon-\zeta$. The incompleteness of the specimen and unknown other parts of exoskeleton complicate closer determination.

\section{Subfamilia, genus et species indet.} Figure 80

Material. - One slightly damaged and deformed cranidium (CGS TW566).

Remarks. - The specimen measures $\sim 2.7 \mathrm{~mm}$ (SL). The cranidium shows close morphology with similar-sized cranidium of Linguaphillipsia noetschensis G. Hahn \& R. Hahn, 1973 (Hahn \& Hahn 1973, text-fig. 7, pl. 1, fig. 4). This is demonstrated mainly by the following features: anterior portion of glabella (near $\beta-\beta$ ) of generally similar width as posterior part of glabella (near $\delta-\delta$ ) - posterior portion only indistinctively broader, glabella slightly constricted near $\gamma$, broadly rounded facial suture around $\beta$, broad fixigena near $\beta$, broadly marked $\mathrm{S} 1$, very short to missing $\varepsilon-\zeta$, similar size and position of palpebral lobes (palpebral lobes placed slightly more frontally in Moravian specimen). Sculpture: the new specimen has transitions between the short ridges and granules on the anterior half of the glabella (the feature not reported in L. noetschensis).

The morphology of fixigena, the course of the facial suture and the outline of the glabella also slightly resemble some ditomopygine taxa, such as Sevillia porcupinensis G. Hahn \& R. Hahn, 1993 (Hahn \& Hahn 1993, pl. 1, fig. 1) and Kaskia chesterensis Weller, 1936 (Chamberlain 1969, pl. 11, fig. 26). Contrary to the Moravian specimen, both these species have a frontal lobe of glabella that is slightly broader than the posterior lobe of glabella, and a narrow and deep S1.
Subfamily Bollandiinae G. Hahn \& Brauckmann, 1988b

Genus Bollandia Reed, 1943

Type species. - Asaphus globiceps Phillips, 1836.

Bollandia megaira (G. Hahn \& R. Hahn, 1970)

Remarks. - This species was originally noted as Griffithides (Bollandia) megaira by Hahn \& Hahn (1970, p. 205). A complete description was published one year later by Hahn \& Hahn (1971, pp. 130-136).

\section{Bollandia megaira brunensis subsp. nov.}

Figures $9 \mathrm{~A}-\mathrm{N}, 10 \mathrm{~A}-\mathrm{G}$

Holotype. - Cranidium CGS TW500 A.

Paratypes. - Two cranidia (CGS TW501 A, 502), four librigenae (CGS TW503, 504, $505 \mathrm{~A}, 512$ ), ten pygidia (CGS TW500 B, C, D; 505 B; 506-511).

Type horizon and locality. - Zetor section near Brno-Líšeň (Moravian Karst, Czech Republic), up to $30 \mathrm{~cm}$ thick trilobite-bearing interval in the succession of the HádyŘičcka Limestone, Líšeň Formation, lower Viséan (MFZ 10 to MFZ 11 foraminifer zones, probably the latter zone).

Etymology. - After Brno (“Bruna” in Latin), the largest city of Moravia, Czech Republic.

Diagnosis. - A subspecies of Bollandia megaira with a glabella somewhat longer than wide, and constricted near $\gamma$. The frontal lobe of the glabella (near $\beta$ ) and posterior part of the glabella (near $\delta$ ) are generally of similar width (tr.), and the frontal lobe of the glabella is only slightly narrower (tr.). S1 is relatively broad and deeply demarcated. Palpebral lobes and eyes are relatively large. Sculpture: cranidium, librigena and pygidium are prevalently covered with relatively coarse granulation with granules commonly penetrated by pores. The prevailing part of the glabella is covered by granules; several relatively coarse terrace ridges separated by areas with sparse granules are developed on the anteriormost part of the glabella. A relatively high number of terrace ridges (approximately six to ten) developed on the lateral border of librigenae. Approximately three to five upper terrace ridges on the lateral border are separated by areas with rows of granules ("terrace ridge-granule row-terrace ridge" pattern). Pygidium with $8+1$ axial rings and five to seven pairs of ribs.

Description. - Cephalic parts: Measurements: holotype cranidium: $\sim 8.8 \mathrm{~mm}$ (SL; CGS TW500 A), para- 
type cranidia: $~ 9.6 \mathrm{~mm}$ (SL; CGS TW501 A) and $\sim 8.0 / 9.5 \mathrm{~mm}$ (ISL/ESL; CGS TW502), paratype librigenae: $\sim 3.6 / 3.9 \mathrm{~mm}$ (ILA/ELA; CGS TW512) to $\sim 8.3 \mathrm{~mm}$ (LA; CGS TW503). Cranidia have a relatively thick exoskeleton. Glabella is longer than wide, slightly constricted near $\gamma$. The frontal lobe is slightly narrower than posterior portion of the glabella. The broad and deep S1 is clearly demarcated and does not reach the occipital furrow; $\mathrm{S} 2$ is very indistinctively developed or absent, S3-S4 not observed. The palpebral lobe is large and slightly variable in length (exsag.): the holotype cranidium (Fig. 9A-D) has a slightly larger palpebral lobe than paratype cranidium (Fig. 9E-G) and this variability in the palpebral lobe is also suggested by the morphology of eyes on the paratype librigenae (Fig. 9H, J, L). The eye is large, and high in lateral view. A median tubercle is developed on the occipital ring. The posterior border furrow is broad and shallow; lateral border furrow very shallow to indistinctive. With the exception of palpebral lobes, the fixigena is narrow and close to glabella. Cranidium and librigenae are prevalently covered by coarse granules, some of them penetrated by pores. The anterior border is covered by approximately six to ten terrace ridges. Several terrace ridges separated by narrow areas with sparse granules are developed in the steeply inclined anteriormost part of the glabella near the anterior border (Fig. 9B, C, F, G). Librigenal field is covered by granulation; a "circumocular" row of granules [similar to B. megaira megaira (G. Hahn \& R. Hahn, 1970), see Hahn \& Hahn 1971] is more or less clearly developed (cf. Fig. 9J, K, L, H). The lateral border bears up to around ten terrace ridges. Approximately three to five upper terrace ridges on the lateral border are separated by narrow areas with granule rows ("terrace ridge-granule rowterrace ridge" pattern, Fig. 9K, M). Hypostoma unknown.

Pygidia: The specimens measure between $\sim 5.0 \mathrm{~mm}$ (SL; CGS TW500 B) to $~ 9.0 / 10.7 \mathrm{~mm}$ (ISL/ESL; CGS TW510). The available pygidia have $8+1$ axial rings and five to seven rib pairs; the last one or two rib pairs are more or less clearly developed. Both interpleural and pleural furrows are developed and relatively firmly impressed; the pleural and interpleural furrow of one or two of the last ribs is almost absent or absent, and the ribs might be marked by rows of granules only. The pygidial border, lateral lobes and axis are covered by granulation.
Some granules are penetrated by pores, although the number and location of penetrated granules is variable, and in some pygidia less common. Granulation on the pygidial border seems to be relatively homogenous. One or two terrace ridges are developed on the lower margin of pygidial border (Fig. 10D, E, G). The granulation on axial rings is mostly coarser in central parts and finer in lateral parts of the rings. The posterior portions of rib pairs have mostly coarser granulations than the anterior portions of ribs (separated by pleural furrow).

Remarks. - The surface of the glabella that is almost completely covered by granules in B. megaira brunensis subsp. nov. suggests a closer affinity to the tisiphone branch, sensu Hahn \& Hahn (2016), because transverse terrace ridges typical of the claviceps branch sensu Hahn \& Hahn (2016) are present only locally in the steeply inclined anteriormost part of the glabella near the anterior border. The holotype cranidium of B. megaira brunensis is similar to B. megaira megaira ( $c f$. Hahn \& Hahn 1971) but it mainly differs in the presence of transverse terrace ridges in the anteriormost part of the glabella and slightly more semi-circular and indistinctively larger palpebral lobe. Pores penetrating some granules, as well as a "terrace ridge-granule row-terrace ridge" pattern on the lateral border were not recorded by the previous authors (Hahn \& Hahn 1971, 2016; Hahn et al. 2003; Müller 2007) in two previously known subspecies of $B$. megaira. Both these subspecies also differ by having smooth pygidia without sculpture (B. megaira megaira), or almost without sculpture, with only locally present granulation on the axial rings (B. megaira scotos G. Hahn, R. Hahn \& Müller, 2003), whereas the new taxon has a pygidium entirely or almost entirely covered by granulation. B. megaira scotos differs especially in having a very broad (tr.) pygidium (see Hahn et al. 2003). The cranidium of an undetermined subspecies of $B$. megaira reported by Müller (2007) and Müller \& Hahn (2018) seems to have a somewhat narrower frontal lobe of the glabella and slightly smaller palpebral lobes. Bollandia tisiphone (G. Hahn \& R. Hahn, 1970) differs in the considerably narrower frontal lobe of glabella (Hahn \& Hahn 1971, Hahn et al. 1998). Bollandia frechi (Scupin, 1900) differs by the having narrow band-like eyes, more clearly separated pygidial border and the first rib entering

Figure 9. A-N - Bollandia megaira brunensis subsp. nov.; A-D - holotype, cranidium, CGS TW500 A, dorsal view (A), right lateral view (B) position of figure D marked by dotted line, anterior view (C), detail of surface sculpture of glabella showing some granules penetrated by pores (D); E-G damaged cranidium, CGS TW501 A, dorsal view (E), right lateral view (F), anterior view (G); H - damaged librigena, dorsal view, CGS TW503; I - incomplete cranidium, dorsal view, CGS TW502; J, K damaged librigena, CGS TW504, dorsal view (J), lateral view (K); L, M - damaged librigena, CGS TW505 A, dorsal view (L) - position of the figure M marked by dotted line, detail of lateral border showing "terrace ridge-granule row-terrace ridge" pattern with some granules penetrated by pores (M); N - pygidium, dorsal view, CGS TW500 B. • O-Q - Bollandia aff. megaira brunensis subsp. nov.; librigena, CGS TW501 B; O - dorsal view; P - lateral view - position of figure Q marked by dotted line; Q - detail of lateral border showing "terrace ridge-granule row-terrace ridge" pattern. All specimens coated with ammonium chloride. Scale bars: 2 mm (A-C, E-Q); 0.5 mm (D). 


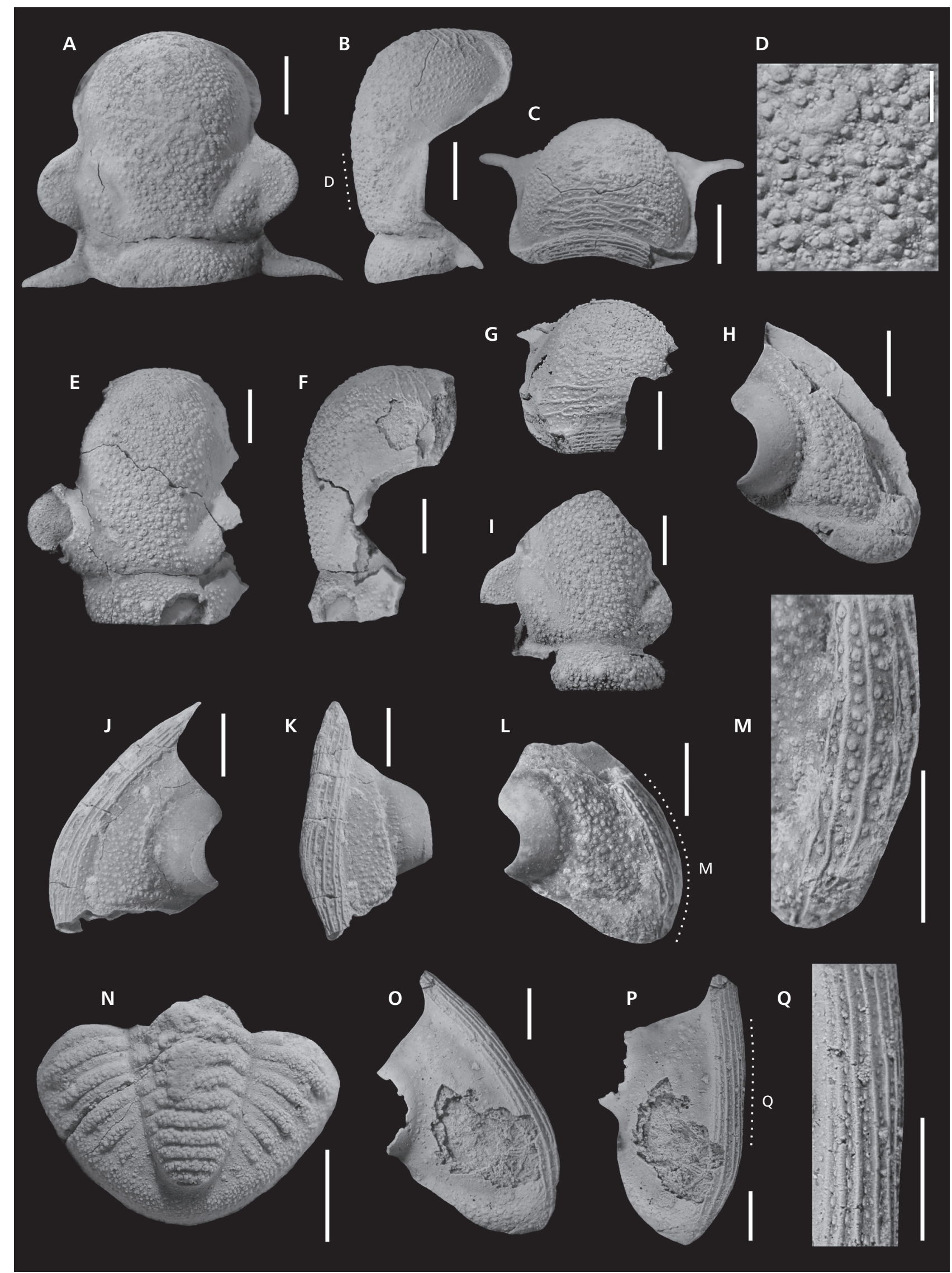


the border (see Hahn \& Hahn 1971, 2016 for detailed descriptions and differences). Bollandia proserpina (G. Hahn, R. Hahn \& Müller, 1998) differs by the smaller eyes, finer sculpture and pygidium, with all ribs (including posterior ones) very sharply and deeply marked (Hahn \& Hahn 2016, Hahn et al. 1998).

Occurrence. - Bollandia megaira brunensis subsp. nov. is currently known only from the type horizon and locality.

\section{Bollandia aff. megaira brunensis subsp. nov.} Figure $90-\mathrm{Q}$

Material. - One cranidium (CGS TW513), one librigena (CGS TW501 B), one pygidium (CGS TW514 A).

Remarks. - Damaged incomplete cranidium (not depicted) measures $\sim 8.7 \mathrm{~mm}$ (SL). The specimen is similar to $B$. megaira brunensis subsp. nov. in rough granulation and only a few short terrace ridges in the steeply inclined anteriormost part of the glabella. A weathered and damaged surface impedes an evaluation of whether the pits developed on the surface represent pores or are only caused by damage in combination with imperfect silicification.

The damaged librigena measures $\sim 11.3 \mathrm{~mm}$ (LA). The assignment of this librigena (Fig. 9O-Q) to other parts of the exoskeleton is not known. This specimen shows very sparse to almost missing granulation on librigenal field. Although damaged, the eye is obviously smaller than in B. megaira brunensis subsp. nov. The lateral border is relatively narrow, but it bears the "terrace ridge-granule row-terrace ridge" pattern similar to the new subspecies.

The pygidium (not depicted) measures $\sim 8.1 \mathrm{~mm}$ (SL). The assignment of this pygidium to other parts of the exoskeleton is not known. This specimen has locally numerous small pits, probably caused by weathering. Relatively sharply delimited ribs resemble pygidia assigned to the new taxon but the pores penetrating granules were not clearly recognised.

\section{Bollandia cf. persephone (G. Hahn \& R. Hahn, 1970) Figures $10 \mathrm{I}-\mathrm{N}, 11 \mathrm{~A}-\mathrm{N}$}

Material. - Six cranidia (CGS TW515-520 A), two librigenae (CGS TW531 A, $532 \mathrm{~A}$ ), 11 pygidia (CGS TW521 A, 522-530, 573).

Description. - Cranidia: The specimens measure between $\sim 4.7 \mathrm{~mm}$ (SL; CGS TW517) to $\sim 8.5 \mathrm{~mm}$ (SL; CGS TW518). The cranidia determined as Bollandia cf. persephone show characteristic surface sculpture of the glabella which was previously recorded in $B$. persephone (see Hahn \& Hahn 1971, Rak \& Lerosey-Aubril 2009): if preserved, the anterior quarter (or third) of the glabella is covered by relatively fine terrace ridges; and the posterior three quarters of the glabella are covered by relatively coarse granulation which progressively merges with terrace ridges on the frontal lobe of the glabella. Granules penetrated by pores were not observed. As far as can be determined, the frontal lobe of glabella (near $\beta$ ) is of the similar width as the posterior portion of glabella (near $\delta$ ) although this feature is slightly variable, for example in one specimen (Fig. 11J) the frontal lobe of the glabella is slightly broader. The cranidia are represented by somewhat narrower and broader morphotypes (Fig. 11K $v s$ Fig. 11E). The size of the palpebral lobes (in relation to the sagittal length of the glabella) is also variable. The variation in relative exsagittal length of palpebral lobe (in relation to sagittal length of the glabella) was observed: the specimen with longest (exsag.) palpebral lobe (Fig. 11E) has a palperal lobe about $\times 1.6$ longer (exsag.) than specimen with shortest (exsag.) palpebral lobe (Fig. 11F). The other three specimens have palpebral lobes of transitional exsagittal lengths (Fig. 11A, J, K). The overall outline of palpebral lobes varies between relatively semielliptic to slightly subtriangular. The constriction of the glabella near $\gamma$ is also variable, in some specimens rather markedly constricted glabella is present (Fig. 11J, K). The $\varepsilon-\zeta$ vary between straight to somewhat curved. S0 is relatively clearly demarcated. S1 is relatively indistinctively developed (e.g. Fig. 11J, F) to faintly visible (e.g. Fig. 11E).

Librigenae: The specimens measure $\sim 6.7 \mathrm{~mm}$ (LA; CGS TW532 A) to $\sim 9.0 / 9.2 \mathrm{~mm}$ (ILA/ELA; CGS TW531 A). Both librigenae (Fig. 11L-N) have large eyes and a relatively high number of terrace ridges on the lateral border (approximately eight or more). The eyes are high in lateral view. The eye of one librigena (Fig. 11M)

Figure 10. A-G - Bollandia megaira brunensis subsp. nov.; A - damaged pygidium, dorsal view, CGS TW506; B - damaged pygidium, dorsal view, CGS TW510; C-G - damaged pygidium, CGS TW511, dorsal view (C) - position of figure G marked by dotted line, left lateral view (D), posterior view (E), ventral view (F) - see attached tube-like epibionts in anterior part of pleural area, detail of surface sculpture of the border with some granules penetrated by pores $(\mathrm{G}) \cdot \bullet \mathrm{H}-$ Bollandia $\mathrm{sp} .1$; pygidium, dorsal view, CGS TW534a. $・ \mathrm{I}-\mathrm{N}$ - Bollandia cf. persephone (G. Hahn \& R. Hahn, 1970); I - detail of surface sculpture on the border showing transitions between granules (without pores) and relatively short terrace ridges, CGS TW527, see figure $\mathrm{M}$ for position of this detail picture; J - pygidium, dorsal view, CGS TW521 A; K - pygidium, dorsal view, CGS TW525; L - damaged pygidium, dorsal view, CGS TW529; M - pygidium, dorsal view, CGS TW527; N - pygidium, dorsal view, CGS TW523. All specimens coated with ammonium chloride. Scale bars: $2 \mathrm{~mm}(\mathrm{~A}-\mathrm{F}, \mathrm{H}, \mathrm{J}-\mathrm{N}) ; 0.5 \mathrm{~mm}(\mathrm{G}, \mathrm{I})$. 


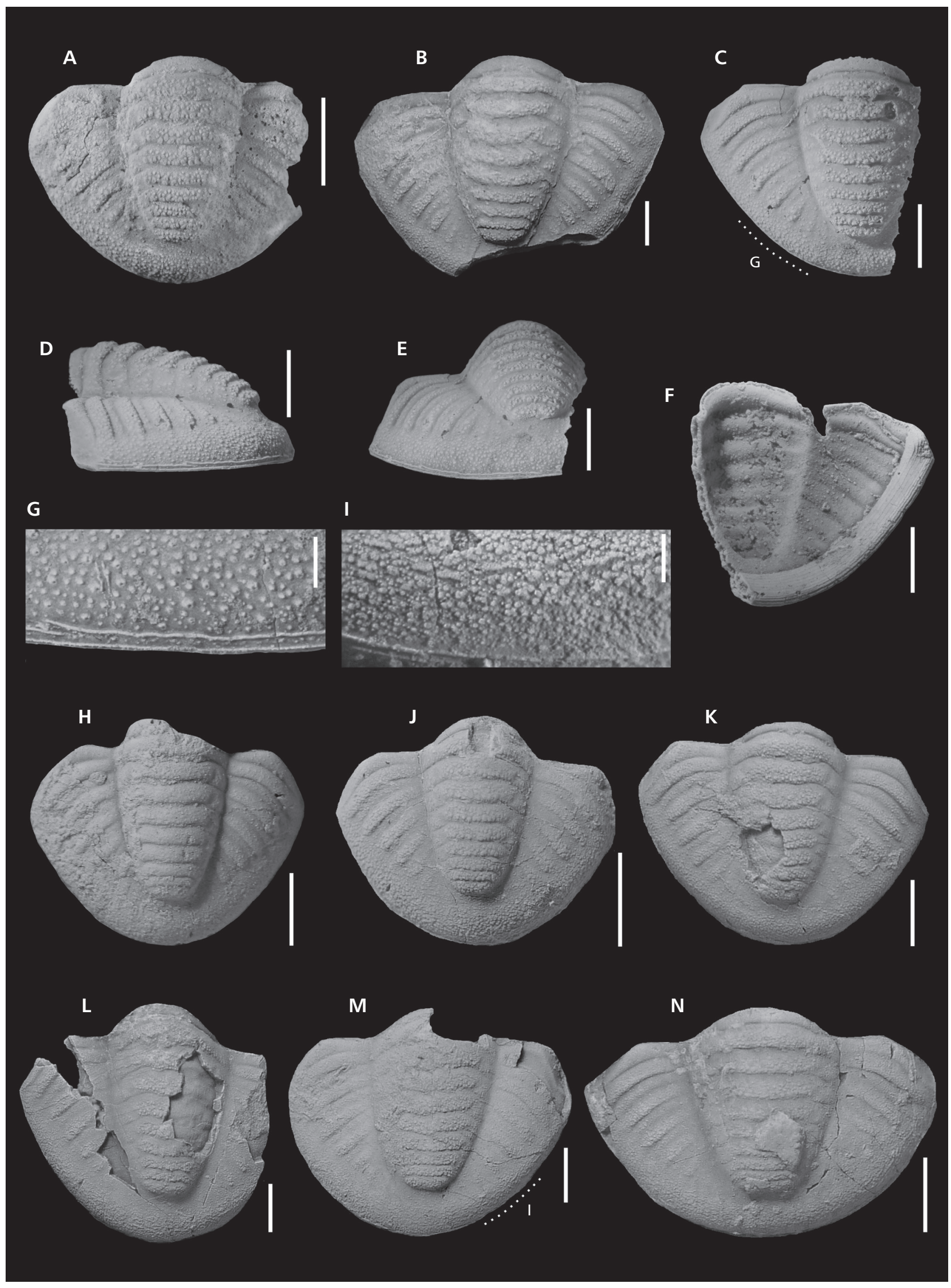


suggests a medium-sized palpebral lobe which approximately corresponds to the medium-sized or larger palpebral lobes recorded in the above mentioned cranidia of the $B$. cf. persephone. The upper portion of the eye in another librigena (Fig. 11L) is partly broken off, which does not allow a closer estimation of palpebral lobe size. The genal angle is rounded (Fig. 11L) or not preserved (Fig. 11M). Sculpture: Relatively coarse granulation developed especially on the broadest (tr.) portions of the librigenal field - the feature is relatively distinctive (Fig. 11L) to rather indistinctive (Fig. 11M); the narrow anterior part of the librigenal field is generally smooth. The granules have no pores.

Pygidia: The specimens measure $\sim 4.9 \mathrm{~mm}$ (SL; CGS TW521 A) to $\sim 10.0 \mathrm{~mm}$ (SL; CGS TW529). The pygidia determined as Bollandia cf. persephone are represented by morphotypes which have the following features: $8+1$ axial rings and about five to six rib pairs with the sixth pair very indistinct; pleural and interpleural furrows developed, pleural furrow poorly visible or absent on last one or two ribs; ribs are generally not extended on the pygidial border. Sculpture: the pygidia are more or less continuously covered by granulation. The border of the pygidium shows some granules slightly elongated and, in some cases merging into short terrace ridges. Although the number and length of terrace ridges on the border varies somewhat in the newly recorded specimens, granules always clearly dominate. Granulation of the pleural area is generally finer and almost absent in some specimens, whereas the pygidial borders and upper portions of axial rings tend to have coarser granules. Granules penetrated by pores are completely absent in the most of specimens or very rarely present (in one specimen: Fig. 10L). The pygidia are variable in width/length ratio $(\mathrm{W} / \mathrm{L})$ and pygidium width/axis width ratio ( $\mathrm{PW} / \mathrm{AW})$. The narrowest (tr.) complete pygidium (Fig. 10J) has a W/L of 1.24 and PW/AW of 2.43, whereas the widest pygidium (Fig. $10 \mathrm{~N}$ ) has a W/L of 1.63 and PW/AW of 2.39. A relatively narrow specimen with relatively broad axis was also recorded, however (Fig. 10M).

Remarks. - Larger palpebral lobes in some specimens and more constricted glabella are more similar to Bollandia torionis Gandl, 1977 (species closely related to B. persephone; $c f$. Hahn \& Hahn 1971, Gandl 1977).
In contrast with the new specimens, the partly damaged paratype librigena of $B$. persephone has only 2-3 terrace ridges visible on the anterior part of the lateral border and has a slightly smaller eye in relation to the overall size of the librigena (Hahn \& Hahn 1971). The rather high number of terace ridges on the lateral border is also similar to B. torionis. However, granules merging into very short ridges on the pygidial border are developed on upper Tournaisian pygidia from the Mokrá quarry (Rak \& Lerosey-Aubril 2009) which were designated by Hahn \& Hahn (2016) as paratype specimens of $B$. persephone. The border almost fully or fully covered by terrace ridges (characteristic feature of Bollandia torionis, see Gandl 1977) was not observed in the new pygidia (Fig. 10I). The sculpture of all new pygidia is thus closer to B. persephone.

The specimens are left in open nomenclature because for the following reasons: Bollandia persephone was described on relatively few specimens (see Hahn \& Hahn 2016 and references therein), and intraspecific variability is thus relatively poorly known - especially the variability of librigenae. The paratype specimens of $B$. persephone from Moravia listed by Hahn \& Hahn (2016) are slightly stratigraphically older (MFZ8, upper Tournaisian, Rak \& Lerosey-Aubril 2009) than the Zetor section and Hahn \& Hahn (1971) noted a cuII $\gamma$ stage (probably upper Tournaisian) for type specimens from Germany. It is possible that morphotypes from slightly different stratigraphic levels might show different morphological trends and might also represent different taxa. It can be supposed that new specimens from the Zetor section, assigned to Bollandia cf. persephone, represent more than one species or subspecies, which might be demonstrated, for example, by the variability of the palpebral lobe, variable constriction of the glabella and width of pygidia and axis (tr.). However, the assignment between various morphotypes of pygidia and cranidia is currently equivocal and additional material is needed to reasonably interpret intraspecific variability, ontogenetic aspects and consider splitting it into more taxa.

\section{Bollandia sp. 1}

Figure $10 \mathrm{H}$

Material. - Two pygidia (CGS TW533 A; 534a, b).

Figure 11. A-N - Bollandia cf. persephone (G. Hahn \& R. Hahn, 1970); A-D - damaged cranidium, CGS TW517, dorsal view (A), right lateral view (B) - position of figure D marked by dotted line, anterior view (C); D - detail of surface sculpture of glabella showing granules without pores; E - damaged cranidium, anterior view, CGS TW519; F-I - damaged cranidium, CGS TW518, dorsal view (F), right lateral view (G) - position of figure I marked by dotted line, anterior view $(\mathrm{H})$, detail of surface sculpture of glabella showing granules without pores (I); J - cranidium, dorsal view, CGS TW515; K - damaged cranidium, CGS TW520 A; L - damaged librigena, dorsal view, CGS TW532 A; M, N - damaged librigena, CGS TW531 A, dorsal view $(\mathrm{M})$, lateral view $(\mathrm{N}) \cdot \bullet \mathrm{O}-$ Bollandia sp. 2; damaged cranidium, dorsal view, CGS TW535. All specimens coated with ammonium chloride. Scale bars: $2 \mathrm{~mm}$ (A-C, E-H, J-O); $0.5 \mathrm{~mm}$ (D); $1 \mathrm{~mm}$ (I). 


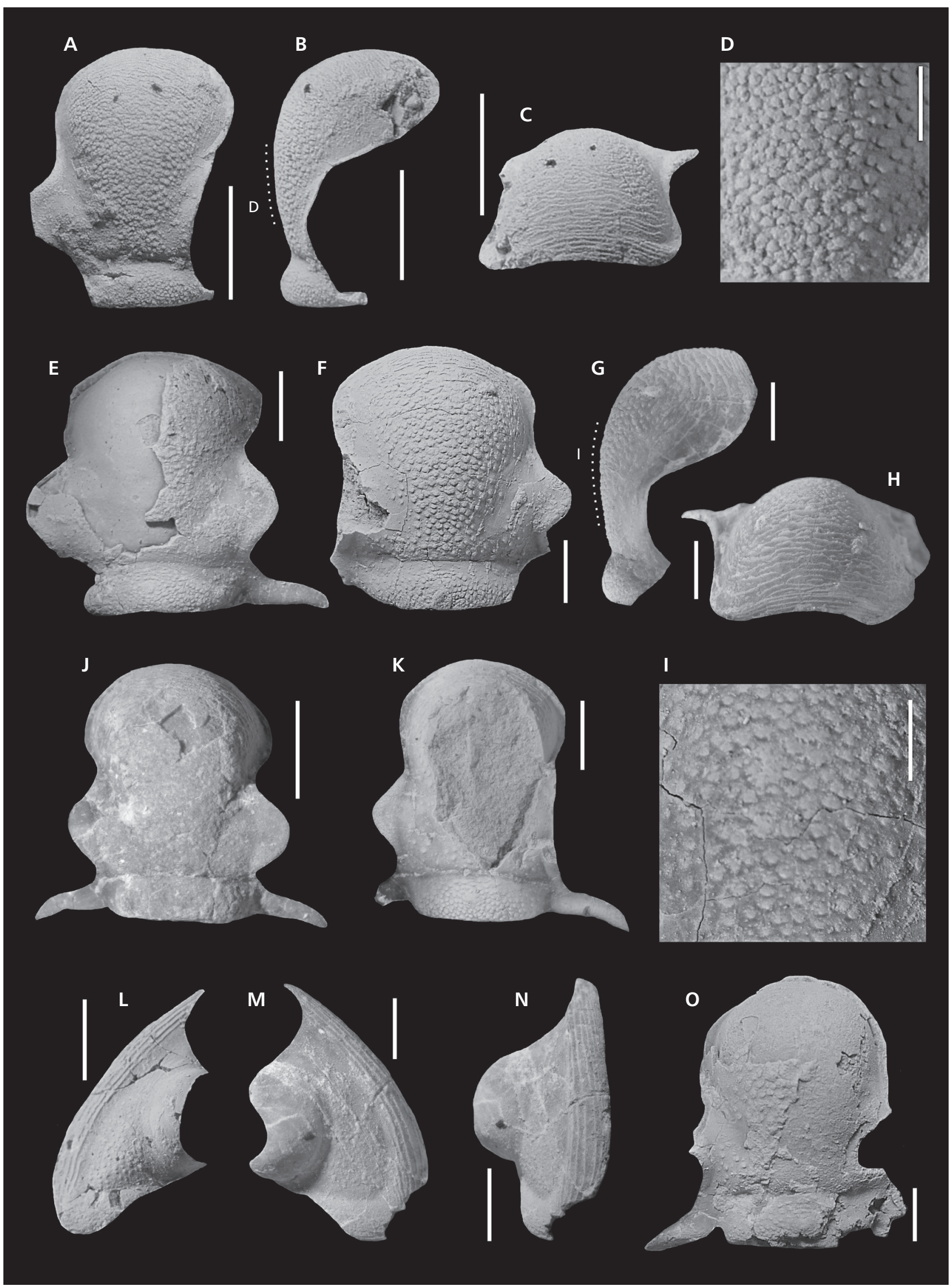


Remarks. - The specimens measure $\sim 6.3 \mathrm{~mm}$ (SL; CGS TW534a) and $7.2 \mathrm{~mm}$ (SL; CGS TW533 A). These pygidia have a semi-elliptic to slightly subtriangular outline, $8+1$ axial rings and five to six rib pairs, with developed pleural and interpleural furrows. Both specimens are very close to the specimens assigned to Bollandia cf. persephone described above, but judging from the slightly weathered surface, the sculpture seems to be generally absent.

\section{Bollandia sp. 2}

Figure 110

Material. - One partly damaged cranidium with librigena (CGS TW535, librigena is weathered and almost completely mechanically destroyed and thus only the cranidium was depicted).

Remarks. - The cranidium measures $\sim 10.3 \mathrm{~mm}$ (SL). The cranidium is mostly exfoliated. The anterior part of the glabella (near $\beta$ ) is of similar width (tr.) as the posterior part (near $\delta$ ). The $\varepsilon-\zeta$ is relatively straight. The palpebral lobe is broken, in comparison with various other Bollandia species (Hahn \& Hahn 1971, 2016) is probably of about medium size. S1 is relatively broad and clearly demarcated, long, but not reaching S0. Rough granules (without pores) are apparent in the central part of the glabella, where remnants of the exoskeleton are preserved. Somewhat finer granules (without pores) are present on the occipital ring and in the area of L1. It is not possible to observe the surface sculpture of anterior part of the glabella, which complicates further taxonomic interpretations.

\section{Discussion}

\section{Comparison and interpretation of trilobite associations}

The first lower Viséan trilobite association from the limestone facies of the Moravian Karst is relatively rich, as suggested by around twenty morphologically diverse taxa, however, the available material is relatively poor in the number of specimens for most of the recorded taxa. Only one new trilobite taxon is formally described, since the assignment between cephalic parts and pygidia seems to be convincing. This currently cannot be stated for other taxa, which are commonly represented by only one or a few specimens, and the assignment between cephalic parts and pygidia is often not certain. Although probably representing new taxa in at least some cases, these specimens are left in open nomenclature to avoid taxonomical oversplitting.

\section{Comparison with other lower Carboniferous trilobite associations from Moravia}

There were previously no data on lower Viséan trilobites (Lower to Middle Viséan, or up to lowermost ?Upper Viséan, cu II $\gamma-\delta$ stage) from clearly carbonate facies in the Moravian Karst. It should be noted that various limestone localities of Chlupáč $(1961,1966)$ were not biostratigraphically revised, but all were assigned to the higher part of the Tournaisian (cuII $\alpha-\beta$ stage), or older strata by this author (see Chlupáč 1966). Trilobite localities previously assigned to the lower part of the Viséan were only known in aleuropelitic shale successions of the Březina Formation. These localities include Březina, valley of the Říčka brook, Zbrašov near Hranice, and Čelechovice (Chlupáč 1966, 1969; Weiner et al. 2012; Rak et al. 2014). With the exceptions of a borehole (Chlupáč 1966) and a surface locality (Weiner et al. 2012) in the valley of the Řícka brook, presence of often abundant blind cystispinine trilobite Spinibole (Spinibole) olgae Chlupáč, 1966 is typical in these localities. This species is associated with further taxa, such as small-eyed archegonids and blind weaniine trilobite Combewoodia (or formerly cystispinine, Hahn et al. 2007 and Müller \& Hahn 2018). These associations are characterised by blind or small-eyed taxa (similarity with atheloptic assemblage sensu Fortey \& Owens 1987; see Weiner et al. 2012, Rak et al. 2014). Another lower Viséan trilobite association from the shale successions of the Březina Formation was recorded in the valley of the Ríčka brook near Brno-Líšen, where somewhat larger-eyed archegonids [Archegonus (Phillibole) cf. polleni (Woodward, 1894), A. (Ph.) cf. cauliquercus (Brauckmann, 1981)] accompanied by small-eyed Liobole glabra proxima Chlupáč, 1966 and perhaps small-eyed or blind ?Spinibole sp. (= ?Combewoodia sp. according to Müller \& Hahn 2018) were recorded (Weiner et al. 2012). The fauna that was recorded by Chlupáč (1966) from a borehole in the valley of the Ríčka brook contained only small-eyed Liobole aff. glabroides [= species of Liobole (Panibole) related to L. (P.) subeaqualis (Holzapfel, 1889) according to Müller \& Hahn 2018] and Cyrtosymbole (Macrobole) sp. (pygidia of probably Archegoninae species of unknown affinity, ?possibly Archegonus Burmeister, 1843 or Cyrtoproetus). The trilobite association from the Zetor section shows some similarities with the association from upper Tournaisian shales of the Březina Formation from the Mokrá quarry near Brno recorded by Rak et al. (2012), where shales alternate with limestone beds (Kalvoda et al. 2010). Bollandia and Liobole (Panibole) are present here (Rak \& Lerosey-Aubril 2009, Rak et al. 2012, Müller \& Hahn 2018), and some other members of Archegoninae and Weaniinae were also recorded from this locality, in some cases without exact stratigraphic position within the 
detrital quartz input

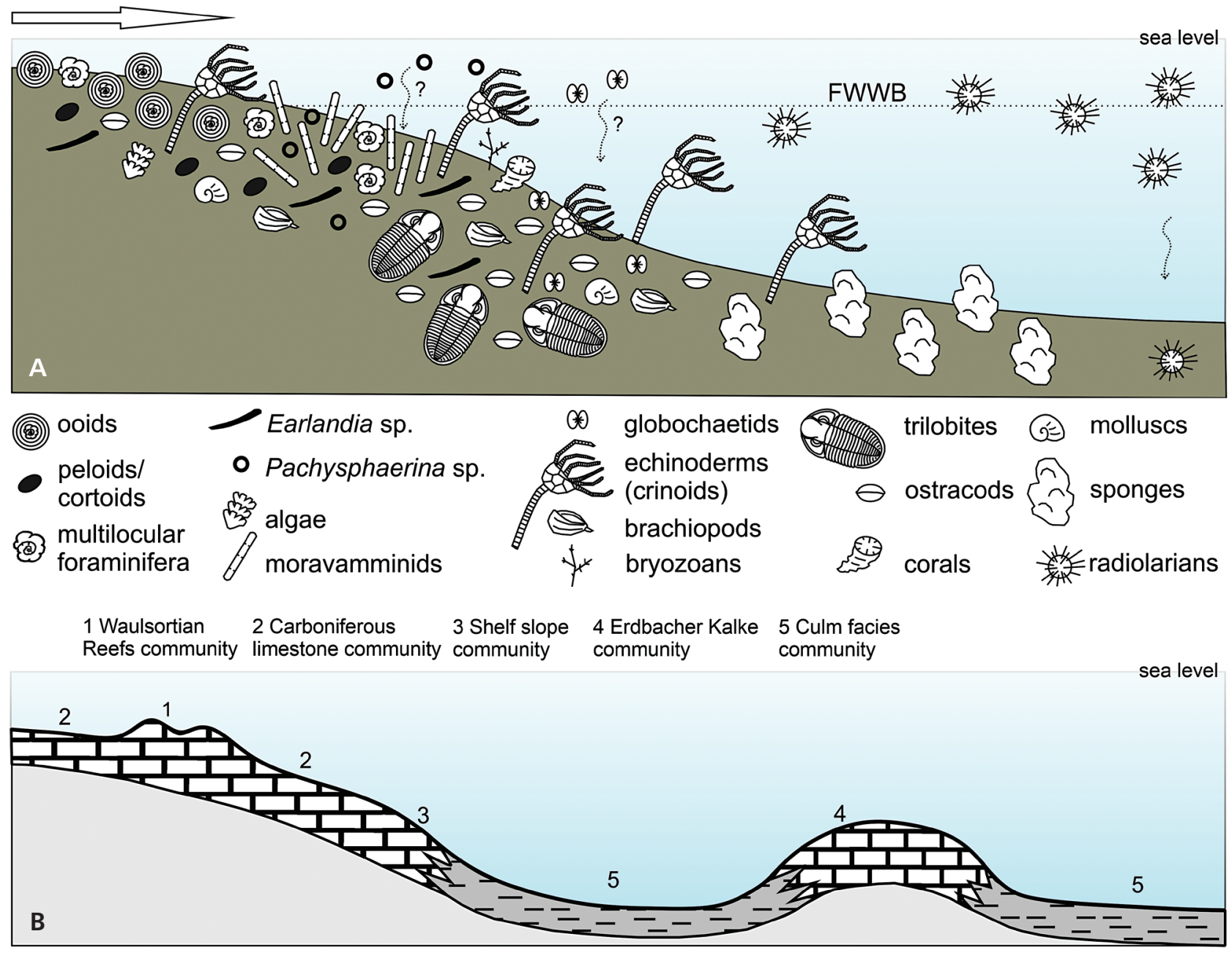

Figure 12. A - interpretative scheme of lower Viséan carbonate environment in the Moravian Karst according to facies and microfacies analysis of the Zetor section, not to scale, FWWB: fair weather wave base. $\bullet$ B - schematic distribution of Carboniferous trilobite communities, based on the definition of Hahn (1990), not to scale.

Tournaisian-Viséan boundary interval (Rak 2004). Rak et al. (2012) determined various trilobite taxa from the Mokrá quarry, based on imperfectly preserved specimens which often makes determination difficult at the specific or even generic level (see note of Müller \& Hahn 2018, p. 14; Hahn et al. 2019, p. 85). Rak et al. (2012) considered this association to be the youngest in the entire Brezina Formation in the Moravian Karst and similar stratigraphic conclusion was published two years later (Rak et al. 2014). We consider the trilobite association from the Mokrá quarry as probably the stratigraphically oldest in the Březina Formation. The late Tournaisian age of trilobites from the Mokrá quarry was precisely documented by foraminifers (Rak et al. 2012). The probable assignment of other trilobite localities in the Březina Formation to the Viséan is supported by the similarity with trilobite associations from other areas (Chlupáč 1966, Owens \& Tilsley 1995, Weiner et al. 2012, Müller \& Hahn 2018).
The trilobite association recorded by Chlupáč (1966) from the "Mokrá II" locality shows some affinity with trilobites from the Zetor section. This is demonstrated by the presence of Liobole (Panibole) testans and Winterbergia egregia; both taxa were also mentioned from the borehole in the valley of the Říčka brook (Chlupáč 1966, p. 16). The locality "Mokrá II" was never biostratigraphically revised and the Tournaisian age supposed by Chlupáč (1966) currently cannot be proved because of landscape changes connected with quarrying activity.

\section{Comparison of the new trilobite association with associations known in other areas}

Many similar trilobite taxa were described from the Erdbach Limestone facies in Rhenish Slate Mountains and Harz Mountains, Germany (e.g. Müller \& Hahn 2018). A very similar list of taxa was recorded from the Liebstein 
locality (near Erdbach, Rhenish Slate Mountains), corresponding to the upper Tournasian anchoralis Zone and partly also to the lower Viséan homopunctatus Zone (see Müller 2007, Müller \& Hahn 2018). The similarity is demonstrated by the occurences of several taxa of Liobole [including, among others, L. (Panibole) galaxaura, L. (P.) paraglabroides and $L$. (L.) trimeroides], Erdbachaspis, Cyrtoproetus, several Weaniinae (e.g., Winterbergia parahahnorum) and two taxa of Bollandiinae (including Bollandia megaira) (see Müller 2007, Müller \& Hahn 2018 for further details). On the other hand, several members of Cystispininae and Archegoninae were recorded from the Liebstein locality and some taxa, such as Gitarra cf. gitarraeformis and Namuropyge, were not noted from here (Müller 2007, Müller \& Hahn 2019). There is no record of Gitarra cf. gitarraeformis from Germany. Gitarra gitarraeformis was described from the Cantabrian Mountains, Spain (Gandl 1977), where it cooccurs with Bollandia torionis (a species closely related to B. persephone, see Gandl 1977), some Liobole taxa [including $L$. $(P$.) valtejana] and some other Archegoninae or Weaniinae (see Gandl 1977 for further details). Specimens which were considered conspecific with G. gitarraeformis are known from Ireland (see Owens 2000 and references therein) and England (Lawrence \& Stammers 2014, Kennedy \& Stammers 2018). According to semi-quantitative data from Gandl (1977, fig. 3), Bollandia torionis is the most abundant trilobite taxon in several localities (e.g. Felmin, Sta. Olaja de la Varga, Veldeteja) in the Cantabrian Mountains, whereas other taxa (e.g. Gitarra gitarraeformis) are less common or rare. On the other hand, trilobites from Liebstein (Erdbach) are mainly represented by Liobole and Cyrtoproetus, whereas Bollandia is infrequent (Müller \& Hahn 2018). At least macroscopically, the most abundant genus in material from the Zetor section is Bollandia (more than 40 specimens) which is accompanied by somewhat less numerous Liobole (around 20 specimens), and other recorded taxa are each represented by only a few specimens or even one specimen. According to microscopic observation of insoluble residuum (conodont samples), most of the closely indeterminable silicified trilobite fragments belong to taxa other than Bollandia, perhaps to Archegoninae or Weaniinae, and the "macroscopic" dominance of Bollandia cannot be clearly proved microscopically.

\section{Environmental interpretation of lower Viséan trilobite associations in the Moravian Karst}

Based on previous works (Hahn \& Hahn 1988, Hahn et al. 1988), Hahn (1990) recognised five different Lower Carboniferous communities dependent on water depth from Belgium and adjacent parts of Germany.
These communities include: the relatively shallower settings of 1) Waulsortian Reefs, and 2) "Carboniferous limestone"; the deeper settings of 3) the "shelf slope community" of the Velbert Anticline, and 4) Erdbacher Kalke (seamount settings); and the most distal, deepest and poorly illuminated settings of 5) "Culm Facies" (Fig. 12B). A further trilobite biofacies scheme for the lower Carboniferous (Asbian stage) of the Craven Basin in North England and North Wales was published by Owens (1990) who similarly recognised different trilobite associations for: A) the carbonate mound, B) basinal shales, and C) shelf/platform carbonates and Yoredale facies. The lower Viséan associations of the Březina Formation correspond to the "Culm facies community" (Hahn 1990) deposited in relatively deep basinal settings, as suggested by the presence of small eyed or blind taxa, especially of Archegoninae and Cystispininae (or Weaniiane in some cases). This association is also close to the basinal shale association of Owens (1990). Owens (1990) expected similar settings for the upper Chadian (lower Viséan) atheloptic trilobite association from North Devon (SW England), which also closely resembles the trilobite association from Březina (Prentice 1967, Owens \& Tilsley 1995, Rak et al. 2014). It can thus be reasonably assumed that Viséan trilobite associations from Březina, Hranice na Moravě, Čelechovice, and probably also the valley of the Říčka brook (Chlupáč 1966, 1969; Weiner et al. 2012; Rak et al. 2014) represent a relatively distal basinal environment. The new trilobite community from the Zetor section resembles the relatively slightly shallower "Erdbacher Kalke" and "Shelf Slope" communities of Hahn (1990) which are characterised by the co-occurrence of deeper-water "Culm facies taxa" and the shallower-water taxa of "Carboniferous limestone" or "neritic carbonates" (see Hahn 1990). The new trilobite association from the Zetor section does not represent an atheloptic assemblage and large-eyed taxa co-occur with small-eyed taxa. This is documented especially by the co-occurrence of relatively abundant small-eyed taxa of Liobole and large-eyed taxa of Bollandia, the latter genus showing relatively higher abundance in the "shelf-slope community" (Hahn 1990), and other large-eyed taxa also occur (e.g. Gitarra, Pseudowaribole). As a result, we consider the lower Viséan trilobite associations of the Březina Formation (Chlupáč 1966, 1969; Weiner et al. 2012; Rak et al. 2014) as possibly representing a more distal siliciclastic basinal environment and the association from the Zetor section as the slightly shallower settings of the lower portions of carbonate shelf slope. However, we also cannot completely exclude the possibility that these associations might represent generally similar water depths reflecting various environments characterised by differences in source areas and bottom topography. 


\section{Conclusions}

(1) The first lower Viséan trilobite association from the clearly carbonate succession of the Líšeň Formation in the Moravian Karst is recorded. The trilobite association is taxonomically diverse and clearly differs from other lower Viséan associations from the Moravian Karst, which were previously described in detail from aleuropelitic facies of the Březina Formation only.

(2) The taxonomical difference between lower Viséan associations of the Březina and Líšeň Formations reflects a similar situation in Germany, where associations similar to those known from the Březina Formation represent a "Culm facies" community sensu Hahn (1990), and the new trilobite association from the Zetor section (Líšeň Formation) resembles Erbacher Kalke and "Shelf Slope" communities (sensu Hahn 1990). The trilobite association is especially taxonomically similar to Erdbach Limestone facies in Germany, but some taxa also show affinities with other areas, especially the Cantabrian Mountains, Spain.

(3) One new taxon, Bollandia megaira brunensis subsp. nov., is defined, and various other taxa which are new at least for the Moravian Karst area in several cases, are discussed.

(4) The trilobite-bearing interval has a unique character within the succession of the Hády-Říčka Limestones at the Zetor section and probably represents allochthonous material derived from the middle or outer parts of the carbonate ramp.

\section{Acknowledgements}

Oldřich Fatka, Ondřej Bábek, Peter Müller and Jindřich Hladil are thanked for helpful discussions. The reviewers Raimund Feist and Allart P. van Viersen, and the editors Petr Budil and Štěpán Manda are greatly acknowledged for their helpful suggestions. The research was financed by the Czech Science Foundation (20-20785J) and was conducted within institutional support RVO 67985831 of the Institute of Geology of the Czech Academy of Sciences.

\section{References}

Adams, A.E., Horbury, A.D. \& Ramsay, A.T.S. 1992. Significance of palaeoberesellids (Chlorophyta) in Dinantian sedimentation, UK. Lethaia 25(4), 375-382. DOI 10.1111/j.1502-3931.1992.tb01640.x

AmLer, M.R.W. \& GereKe, M. 2002. Karbon-Korrelationstabelle (KKT). Senckenbergiana lethaea 82(2), 691-709. DOI 10.1007/BF03042955

Angelin, N.P. 1854. Palaeontologia Scandinavica Pars I, Icono- graphia crustaceorum formationis transitionis, Fasciculus II. 72 pp. (21-92), T.O. Weigel, Lund.

Archinal, A. 1992. Revision der Untergattung Archegonus (Phillibole) (Trilobita, Ober-Devon und Unter-Karbon). Courier Forschungsinstitut Senckenberg 144, 1-133.

BÁBek, O., PřIKryl, T. \& Hladil, J. 2007. Progressive drowning of carbonate platform in the Moravo-Silesian Basin (Czech Republic) before the Frasnian/Famennian event: facies, compositional variations and gamma-ray spectrometry. Facies 53, 293-316. DOI 10.1007/s10347-006-0095-8

BÁbeK, O., FAmĚra, M., ŠImíček, D., Weinerová, H., Hladil, J. \& KalvodA, J. 2018. Sea-level changes vs. organic productivity as controls on Early and Middle Devonian bioevents: Faciesand gamma-ray based sequence-stratigraphic correlation of the Prague Basin, Czech Republic. Global and Planetary Change 160, 75-95.

DOI 10.1016/j.gloplacha.2017.11.009

Böth, L. \& Brauckmann, C. 1979. Bericht über bemerkenswerte neuere Fossil-Funde aus dem Ober-Devon und Karbon des Bergischen Landes. Jahresberichte des Naturwissenschaftlichen Vereins in Wuppertal 32, 106-118.

Brauckmann, C. 1973. Kulm-Trilobiten von Aprath (Bergisches Land). 209 pp. dissertaton thesis, Freien Universität Berlin, Berlin, Germany.

Brauckmann, C. 1974. Neue Trilobiten aus dem Kulm von Aprath bei Wuppertal (Unter-Karbon, Rheinisches SchieferGebirge). Geologica et Palaeontologica 8, 113-117.

Brauckmann, C. 1978. Beiträge zur Kentniss der unter-karbonischen Trilobiten-Fauna von Aprath, Bergisches Land, 2*). Pseudowaribole (Geigibole) Gandl 1968. Senckenbergiana lethaea 59(1/3), 1-27.

Brauckmann, C. 1981. Eine neue Trilobiten-Art aus dem Kulm (Unter-Karbon cu III $\alpha$ ) von Aprath (Wuppertal, W-Deutschland). Jahresberichte des Naturwissenschaftlichen Vereins in Wuppertal 34, 92-95.

Burmeister, H. 1843. Die Organisation der Trilobiten, aus ihren lebenden Verwandten entwickelt; nebst einer systematischen Uebersicht aller zeither beschriebenen Arten: I-XII, 147 pp. Berlin, G. Reimer. DOI 10.5962/bhl.title.9086

Chamberlain, C.K. 1969. Carboniferous trilobites: Utah species and evolution in North America. Journal of Paleontology 43(1), 41-68. DOI 10.1017/S0022336000062466

Chlup'́́, I. 1961. New Lower Carboniferous trilobites from the Moravian Karst. Věstnik Ústředního ústavu geologického 36, 229-234.

Chluṕ́́, I. 1965. Forschritte in der Stratigraphie des Mährischen (Ostsudetischen) Devons. Geologische Rundschau 54, 1003-1025. DOI 10.1007/BF01820769

Chluṕ́č, I. 1966. The Upper Devonian and Lower Carboniferous trilobites of the Moravian karst. Sbornik geologických věd, Paleontologie 7, 1-143.

ChlupÁč, I. 1969. Lower Carboniferous fauna from Čelechovice (Moravia) and its significance. Časopis pro mineralogii a geologii 2, 211-218.

Chlupéč, I. 1988. The Devonian of Czechoslovakia and its stratigraphical significance, 481-497. In McMillan, N.J., Embry, A.F. \& Glass, D.J. (eds) Devonian of the World. 
Proceedings of the Second International Symposium on the Devonian System, Calgary, Canada, Volume I: Regional Syntheses. Canadian Society of Petroleum Geologists.

ChLupÁČ, I. 1992. Middle Devonian trilobites from Čelechovice in Moravia (Czechoslovakia). Sborník geologických věd, Paleontologie 32, 123-161.

Chlupáč, I. 2000. Devonští trilobiti Moravy a Slezska, jejich výskyt a význam. Př́rodovědné studie Muzea Prostějovska 3, 5-26.

Devuyst, F.-X. \& Lees, A. 2001. The initiation of Waulsortian buildups in Western Ireland. Sedimentology 48(5), 1121-1148. DOI 10.1046/j.1365-3091.2001.00411.x

Embry, A.F. \& Klovan, J.E. 1971. A Late Devonian reef tract on Northeastern Banks Island, N.W.T. Bulletin of Canadian Petroleum Geology 19(4), 730-781.

Fortey, R.A. \& Owens, R.M. 1975. Proetida - a new order of trilobites. Fossils \& Strata 4, 227-239.

Fortey, R.A. \& Owens, R.M. 1987. The arenig series in South Wales. Bulletin of the British Museum (Naural History), Geology series 41, 69-307.

Franke, W. 1989. Tectonostratigraphic units in the Variscan belt of central Europe. Geological Society of America Special Papers 230, 67-89. DOI 10.1130/SPE230-p67

Gallagher, S.J. 1998. Controls on the distribution of calcareous Foraminifera in the Lower Carboniferous of Ireland. Marine Micropaleontology 34(3-4), 187-211.

DOI 10.1016/S0377-8398(98)00006-1

GANDL, J. 1968. Stratigraphische Untersuchungen im Unterkarbon des Frankenwaldes unter besonderer Berücksichtigung der Trilobiten, 1: Die Trilobiten im Unterkarbon des Frankenwaldes. Senckenbergiana lethaea 49(1), 39-117.

GandL, J. 1977. Die Karbon-Trilobiten des Kantabrischen Gebirges (NW-Spanien), 2: Die Trilobiten der Alba-Schichten (Unter-Visé bis Namur A). Senckenbergiana lethaea 58(1/3), 113-217.

GandL, J. 1987. Die Karbon-Trilobiten des Kantabrischen Gebirges (NW-Spanien), 4*): Trilobiten aus dem höheren Namur und tieferen Westfal. Abhandlungen der senckenbergischen naturforschenden Gesellschaft 543, 1-79.

GRÖNING, E. 1985. Vier neue Arten der Gattung Liobole (Trilobita; Unter-Karbon) und ihre Einleitung in Untergattungen. Jahresberichte des Naturwissenschaftlichen Vereins in Wuppertal 38, 39-145.

GRöNING, E. 1986. Revision der Gattung Liobole (Trilobita, Unter-Karbon). Courier Forschungsinstitut Senckenberg 80, $1-216$.

Hahn, G. 1965. Revision der Gattung Archegonus Burmeister 1843 (Trilobita). Senckenbergiana lethaea 46(4/6), 229-262.

Hahn, G. 1966. Morphologie, Variabilität und postlarvale Ontogenie von Archegonus (Phillibole) nitidus und Archegonus (Angustibole) winterbergensis (Trilobita, UnterKarbon). Senckenbergiana lethaea 47(4), 347-383.

HAHN, G. 1967. Neue Trilobiten vom Winterberg/Harz (UnterKarbon). Senckenbergiana lethaea 48(2), 163-189.

Hahn, G. 1990. Paleobiogeographic distribution and biostratigraphic significance of Lower Carboniferous trilobites: a review. Courier Forschungsinstitut Senckenberg 130, 199-205.

Hahn, G. \& Brauckmann, C. 1975. Zur Evolution von Carbonocoryphe (Trilobita; Unter-Karbon). Senckenbergiana lethaea 56(4/5), 305-333.

Hahn, G. \& Brauckmann, C. 1984. Zur Kenntnis ober-devonischer Trilobiten aus dem Bergischen Land. Jahresberichte des Naturwissenschaftlichen Vereins in Wuppertal 37 , 116-124.

Hahn, G. \& Brauckmann, C. 1988a. Neue Kulm-Trilobiten aus Wuppertal (Bundesrepublik Deutschland). 1. Weaniinae. Jahresberichte des Naturwissenschaftlichen Vereins in Wuppertal 41, 96-112.

Hahn, G. \& Brauckmann, C. 1988b. Zur Phylogenie der Bollandiinae (Trilobita, Karbon-Perm). Jahresberichte des Naturwissenschaftlichen Vereins in Wuppertal 41, 119-131.

Hahn, G. \& Hahn, R. 1967. Zur Phylogenie der Proetidae (Trilobita) des Karbons und Perms. Zoologische Beiträge, Neue Folge 13(2-3), 303-349.

Hahn, G. \& Hahn, R. 1969. Kulm-Trilobiten von Nehden und Rüthen (Sauerland). Senckenbergiana lethaea 50(4), 273-289.

Hahn, G. \& Hahn, R. 1970. Trilobitae carbonici et permici II. (Proetidae: Griffithidinae). Fossilium Catalogus. I: Animalia 119, 163-331.

Hahn, G. \& HAHN, R. 1971. Revision von Griffithides (Bollandia) (Tril.; Unter-Karbon). Palaeontographica Abteilung A 137(4-6), 109-154.

Hahn, G. \& Hahn, R. 1973. Trilobiten aus dem Unter-Karbon (Dinantium) von Nötsch/Österreich. Geologica et Palaeontologica 7, 135-146.

Hahn, G. \& Hahn, R. 1975. Die Trilobiten des Ober-Devon, Karbon und Perm, I-VIII, 1-127. In Krömmelbein, K. (ed.) Leitfossilien 1. Gebrüder Borntraeger, Berlin \& Stuttgart.

Hahn, G. \& Hahn, R. 1988. The biogeographic distribution of Carboniferous Limestone trilobites in Belgium and adjacent areas. Bulletin de la Société belge de Géologie 97(1), 77-93.

Hahn, G. \& Hahn, R. 1993. Neue Trilobiten-Funde aus dem Karbon und Perm Alaskas. Geologica et Palaeontologica 27, 141-163.

Hahn, G. \& Hahn, R. 1996. Die Trilobiten-Taxa des Karbons und Perms. 2. Brachymetopidae. Courier Forschungsinstitut Senckenberg 195, 1-242.

Hahn, G. \& Hahn, R. 2002. Phylogenie und Systematik von Chlupacula und verwandten Gattungen (Trilobita; UnterKarbon). Geologica et Palaeontologica 36, 45-77.

HAHN, G. \& HAHN, R. 2016. Catalogus trilobitorum cum figuris (Trilobites carbonici et permici, VII. Bollandiinae). Fossilium Catalogus I: Animalia 153, 1-192.

Hahn, G. \& Wunn-Petry, I. 1983. Seltene Trilobiten aus der nasutus-Zone (Kulm-Fazies, Unter-Karbon. Senckenbergiana lethaea 64(2/4), 237-255.

Hahn, G., Hahn, R. \& Brauckmann, C. 1980. Die Trilobiten des belgischen Kohlenkalkes (Unter-Karbon). 1. Proetinae, Cyrtosymbolinae und Aulacopleuridae. Geologica et Palaeontologica 14, 165-188. 
Hahn, G., Hahn, R. \& Brauckmann, C. 1987. Die Trilobiten des belgischen Kohlenkalkes (Unter-Karbon). 9. Piltonia und Nachträge. Geologica et Palaeontologica 21, 137-167.

Hahn, G., Hahn, R. \& Brauckmann, C. 1988. Die Trilobiten des belgischen Kohlenkalkes (Unter-Karbon). 10. Biostratigraphie. Geologica et Palaeontologica 22, 55-72.

Hahn, G., Hahn, R. \& Brauckmann, C. 1994. Trilobiten mit „Drevermannia - Habitus“ im Unter-Karbon. Courier Forschungsinstitut Senckenberg 169, 155-193.

Hahn, G., Hahn, R. \& Müller, P. 1996. 100 Jahre TrilobitenForschung in den Erdbacher Kalken (Unter-Karbon) Zussamenstellung bisheriger Ergebnisse und Beschreibung neuer Taxa. Geologica et Palaeontologica 30, 147-193.

Hahn G., Hahn, R. \& Müller, P. 1998. Trilobiten aus den Erdbacher Kalken (Unter-Karbon) von Steeden in Hessen. Geologica et Paleontologica 32, 161-219.

Hahn, G., Hahn, R. \& MüLler, P. 2001. Trilobiten aus den Erdbacher Kalken (Unter-Karbon) vom Liebstein und Kramberg (Hessen) - Teil. 2. Geologica et Palaeontologica 35, 81-103.

Hahn, G., Hahn, R. \& Müller, P. 2003. Trilobiten aus den Erdbacher Kalken (Unter-Karbon) von Steeden in Hessen Teil 2. Geologica et Palaeontologica 37, 33-75.

Hahn, G., Hahn, R. \& Müller, P. 2007. Trilobiten aus dem UnterKarbon (Ober-Erdbachium, nasutus-Zone) vom Homberg bei Erdbach (Hessen). Geologica et Palaeontologica 41, 81-93.

Hahn, G., Hahn, R. \& Becker, R.T. 2012. Unter-karbonische Trilobiten aus dem Anti-Atlas (S-Marokko). Geologica et Palaeontologica 44, 37-74.

Hahn, G., Hahn, R. \& Müller, P. 2019. Catalogus trilobitorum cum figuris (Trilobites devonici, carbonici et permici, IX. Cystispininae, Globusiinae, Proetinae). Fossilium Catalogus I: Animalia 159, 1-335. Margraf Publishers, Weikersheim.

Hahn, R. 1967. Neue Trilobiten aus dem Kulm von Herborn und Erdbach. Senckenbergiana lethaea 48(2), 99-105.

HAHN, R. 1968. Proetidae aus der oberen crenistria-Zone von Herborn. (Trilobita; Unter-Karbon). Teil 1: Archegonus (Archegonus) Burmeister 1843. Senckenbergiana lethaea 49(2/3), 193-233.

Hawle, I. \& Corda, A.J.C. 1847. Prodrom einer Monographie der böhmischen Trilobiten. Böhmischen Gesellschaft der Wissenschaften, Abhandlungen 5, 1-176.

Hennebert, M. \& Lees, A. 1991. Environmental gradients in carbonate sediments and rocks detected by correspondence analysis: examples from the Recent of Norway and the Dinantian of southwest England. Sedimentology 38(4), 623-642. DOI 10.1111/j.1365-3091.1991.tb01012.x

Herbig, H.-G. 2016. Mississippian (Early Carboniferous) sequence stratigraphy of the Rhenish Kulm Basin, Germany. Geologica Belgica 19(1-2), 81-110.

DOI $10.20341 / \mathrm{gb} .2016 .010$

HLADIL, J. 1983. The biofacies section of Devonian limestones in the central part of the Moravian Karst. Sbornik geologických Véd, Geologie 38, 71-94.

HLADIL, J. 1992. Zonality of the Devonian sediments in Moravia (ČSFR), 121-126. In KuKaL, Z. (ed.) Proceedings of the $1^{\text {st }}$ International Conference on the Bohemian Massif, Praha.
Hladil, J., Krejci, Z., Kalvoda, J., Ginter, M., Galle, A. \& BeROUSEK, P. 1991. Carbonate ramp environment of Kellwasser time-interval; Lesni lom, Moravia, Czechoslovakia. Bulletin de la Société Belge de Géologie 100(1-2), 57-119.

Holzapfel, E. 1889. Die cephalopoden-führenden Kalke des unteren Carbon von Erdbach-Breitscheid bei Herborn. Palaeontologische Abhandlungen 5, Neue Folge 1(1), 3-74.

Kalvoda, J. 1998. The Main Phases of extension in the eastern part of the Rhenohercynian Zone. Acta Universitatis Carolinae, Geologica 42(2), 274-275.

Kalvoda, J., Melichar, R., Bábek O., \& Leichmann, J. 2002. Late Proterozoic-Paleozoic tectonostratigraphic development and paleogeography of Brunovistulian Terrane and comparison with other terranes at the SE margin of BalticaLaurussia. Journal of the Czech Geological Society 47(3-4), 81-102.

Kalvoda, J., Leichmann, J., Bábek, O. \& Melichar, R. 2003. Brunovistulian Terrane (Central Europe) and Istanbul Zone (NW Turkey): Late Proterozoic and Paleozoic tectonostratigraphic development and paleogeography. Geologica Carpathica 54, 139-152.

Kalvoda, J., Bábek, O., Fatka, O., Leichmann, J., Melichar, R. \& ŠPAČEK, P. 2008. Brunovistulian terrane (Bohemian Massif, Central Europe) from late Proterozoic to late Paleozoic: a review. International Journal of Earth Sciences 97, 497-518. DOI 10.1007/s00531-007-0183-1

Kalvoda, J., Devyust, F.-X., BÁbek, O., Dvořák, L., Rak, Š. \& ReZ, J. 2010. High-resolution biostratigraphy of the Tournaisian-Visean (Carboniferous) boundary interval, Mokrá quarry, Czech Republic. Geobios 43, 317-331. DOI 10.1016/j.geobios.2009.10.008

Kalvoda, J., Kumpan, T. \& BÁBeK, O. 2015. Upper Famennian and Lower Tournaisian sections of the Moravian Karst (Moravo-Silesian Zone, Czech Republic): a proposed key area for correlation of the conodont and foraminiferal zonations. Geological Journal 50, 17-38. DOI 10.1002/gj.2523

Kennedy, R. \& Stammers, S. 2018. Trilobites of the British Isles. 384 pp. Siri Scientific Press, Manchester, UK.

Lawrence, P. \& Stammers, S. 2014. Trilobites of the World. An atlas of 1000 photographs. 416 pp. Siri Scientific Press, Manchester, UK.

Leyh, C.F. 1897. Beiträge zur Kenntniss des Paläozoikum der Umgegend von Hof a. Saale. Zeitschrift der Deutschen Geologischen Gesellschaft 49, 504-560.

Madi, A., Bourque, P.-A. \& Mamet, B.L. 1996. Depth-related Ecological Zonation of a Carboniferous Carbonate Ramp: Upper Viséan of Béchar Basin, Western Algeria. Facies 35(1), 59-80. DOI 10.1007/BF02536957

Meyer, H. von 1831. Beiträge zur Petrefactenkunde. Beschreibung der Orthoceratites striolatus und über den Bau und das Vorkommen einiger vielkammerigen fossilen $\mathrm{Ce}$ phalopoden; nebst der Beschreibung von Calymene aequalis. Verhandlungen der Kaiserlichen LeopoldinischCarolinischen Akademie der Naturforscher, 2. Abtheilung 15, 59-112.

Müller, P. 2004. Eine Trilobiten-Assoziation aus den Erdbach- 
Kalken (Unter-Karbon) vom Liebstein (Hessen). Geologica et Palaeontologica 38, 57-83.

MüLLER, P. 2007. Seltene Trilobiten aus dem Erdbach-Kalk vom Liebstein bei Erdbach (Unter-Karbon; Hessen). Geologica et Palaeontologica 41, 27-45.

Müller, P. \& Hahn, G. 2018. Die Trilobiten der Erdbach-Kalke von Erdbach (Hessen) und die der „Phillipsien-Bank“ im Raum Warstein (Nord-rhein-Westfalen), sowie eine Revision der Cystispininae (mittleres Mississippium). Abhandlungen der Senckenberg Gesselschaft für Naturforschung 574, $1-237$.

Müller, P. \& Hahn, G. 2019. Eine neue Trilobiten-Fauna aus dem Mississippium von Rösenbeck (Nordrhein-Westfalen, Deutschland). Dortmunder Beiträge zur Landeskunde, naturwissenschaftliche Mitteilungen 49, 93-161.

Mullins, H.T. \& Cook, H.E. 1986. Carbonate apron models: Alternatives to the submarine fan model for paleoenvironmental and hydrocarbon exploration. Sedimentary Geology 48(1-2), 37-79. DOI 10.1016/0037-0738(86)90080-1

OenLert, M.D. 1886. Étude sur quelques trilobites au groupe des Proetidae. Bulletin de la Société d'Ėtudes scientifiques d'Angers, nouvelle série 15, 1-23.

Okuyucu, C., Vachard, D. \& GöNCÜOĞLu, M.C. 2013. Refinements in biostratigraphy of the foraminiferal zone MFZ11 (late early Viséan, Mississippian) in the Cebeciköy Limestone (Istanbul Terrane, NW Turkey) and palaeogeographic implications. Bulletin of Geosciences 88(3), 621-645.

DOI 10.3140/bull.geosci.1387

Oppenheimer, J. 1930. Neue Beiträge zur Geologie des Oberdevons von Brünn. Sbornik Státního geologického Ústavu Československé republiky 9, 219-234.

OsmólsKa, H. 1962. Famennian and Lower Carboniferous Cyrtosymbolinae (Trilobita) from the Holy Cross Mountains, Poland. Acta Palaeontologica Polonica 7, 53-222.

Osmólska, H. 1968. Contributions to the Lower Carboniferous Cyrtosymbolinae. Acta Palaeontologica Polonica 13(1), 119-150.

OsmólsKa, H. 1970. On some rare genera of the Carboniferous Cyrtosymbolinae Hupé, 1953 (Trilobita). Acta Palaeontologica Polonica 15(1), 115-131.

Owens, R.M. 1983. A review of Permian trilobite Genera. Special Papers in Paleontology 30, 15-41.

Owens, R.M. 1990. Carboniferous trilobites: the beginning of the end. Geology Today 6, 96-100.

DOI 10.1111/j.1365-2451.1990.tb00715.x

Owens, R.M. 2000. The Carboniferous trilobites from Ireland described by Phillips, Portlock, McCoy and Woodward. Irish Journal of Earth Sciences 18, 1-32.

Owens, R.M. \& Tilsley, J.W. 1995. An atheloptic trilobite assemblage from the Carboniferous of North Devon. Geological Magazine 132, 713-728. DOI 10.1017/S0016756800018938

Phillips, J. 1836. Illustrations of the geology of Yorkshire; or, a description of the strata and organic remains: accompanied by a geological map, sections, and plates of the fossil plants and animals. Part II. The Mountain Limestone District. 253 pp. John Murray, London. DOI 10.5962/bhl.title.127948
Poty, E., Devuyst, F.-X. \& Hance, L. 2006. Upper Devonian and Mississippian foraminiferal and rugose coral zonations of Belgium and northern France: a tool for Eurasian correlations. Geological Magazine 143(6), 829-857. DOI $10.1017 / \mathrm{S} 0016756806002457$

Poty, E., Aretz, M. \& Hance, L. 2014. Belgian substages as a basis for an international chronostratigraphic division of the Tournaisian and Viséan. Geological Magazine 151(2), 229-243. DOI 10.1017/S0016756813000587

PoukArová, H. 2014. Kompoziční analýza karbonátů na vybraných profilech při hranici tournai/visé. $77 \mathrm{pp}$. Master thesis, Masaryk University, Brno, Czech Republic.

Prentice, J.E. 1967. Lower Carboniferous trilobites of North Devon and related species from Northern England. Bulletin of the British Museum (Naural History), Geology 14(6), 207-241.

RAK, Š. 2004. Trilobitová fauna hraničních vrstev tournai - visé z Mokré u Brna. 67 pp. Master thesis, Masaryk University, Brno, Czech Republic.

RAK, Š. \& Lerosey-Aubril, R. 2009. First record of the Carboniferous trilobite Bollandia from the Moravian Karst (Czech Republic) and its significance. Bulletin of Geosciences 84(4), 739-744. DOI 10.3140/bull.geosci.1154

Rak, Š., Kalvoda, J. \& Devuyst, F.-X. 2012. New Mississippian trilobite association from the Brno vicinity and its significance (Moravian Karst, Czech Republic). Geologica Carpathica 63(3), 181-190. DOI 10.2478/v10096-012-0015-5

RAK, Š., VIKTORÝN, T. \& OTAVA, J. 2014. Revison of an atheloptic Visean Trilobite association in the Moravian Karst (Czech Republic). Geologica Carpathica 65(6), 411-417. DOI 10.1515/geoca-2015-0002

Reed, F.R.C. 1899. Woodwardian Museum notes: A new carboniferous trilobite. Geological Magazine, new series, decade 4, vol. 6, 241-245. DOI 10.1017/S0016756800143110

Reed, F.R.C. 1943. The genera of British Carboniferous trilobites. The Annals and Magazine of Natural History 10(61), 11. series, 54-65. DOI 10.1080/00222934308527317

Rez, J., Melichar, R. \& Kalvoda, J. 2011. Polyphase deformation of the Variscan accretionary wedge: an example from the southern part of the Moravian Karst (Bohemian Massif, Czech Republic), 223-235. In Poblet, J. \& Lisle, R.J. (eds) Kinematic Evolution and Structural Styles of Fold-and-Thrust Belts. Geological Society London, Special Publication 349. DOI 10.1144/SP349.12

Richter, R. \& Richter, E. 1926. Die Trilobiten des Oberdevons. Beiträge zur Kenntnis devonischer Trilobiten IV. Abhandlungen der Preußischen Geologischen Landesanstalt, Neue Folge 99, 1-314.

Richter, R. \& Richter, E. 1939. Ueber Namuropyge n. g. und die Basisolution der Trilobiten-Glatze. Bulletin du Musée royal d'Historie naturelle de Belgique 15(3), 1-29.

Richter, R. \& Richter, E. 1949. Die Trilobiten der Erdbach Zone (Kulm) im Rheinischen Schiefergebirge und in Harz. 1. Die Gattung Phillibole. Senckenbergiana 30(1/3), 63-94.

Richter, R. \& Richter, E. 1951. Der Beginn des Karbons im Wechsel der Trilobiten. Senckenbergiana lethaea 32(1/2), 219-266. 
Scupin, H. 1900. Die Trilobiten des niederschleisichen Unterkarbon.Zeitschrift der Deutschen Geologischen Gesellschaft 1, $1-20$.

SкомPSKI, S. 1987. The dasycladacean nature of Late Paleozoic palaeoberesellid algae. Acta Geologica Polonica 37(1-2), 21-31.

Synek, J. 1997. Devonské vápence v okoli Bedřichovic. 68 pp. Master thesis, Masaryk University, Brno, Czech Republic.

SyneK, J. 1999. Devonian and Lower Carboniferous limestones in the southernmost part of the Moravian Karst. Acta Musei Moraviae, Scientae geologicae 84, 89-96.

VACHARD, D. \& Cózar, P. 2010. An attempt of classification of the Palaeozoic incertae sedis Algospongia. Revista Española de Micropaleontología 42(2), 129-241.

Vachard, D., Pille, L. \& Gaillot, J. 2010. Palaeozoic Foraminifera: Systematics, palaeoecology and responses to global changes. Revue de micropaléontologie 53, 209-254. DOI 10.1016/j.revmic.2010.10.001

Vachard, D., Coronado, I., Izart, A. \& Cózar, P. 2018a. Foraminifers in the latest Tournaisian-late Viéan of southern France (southern Montagne Noire and Mouthoumet Massif). Geobios 51, 219-230. DOI 10.1016/j.geobios.2018.04.007

VAchard, D., KReiner, K. \& Mörtl, A. 2018b. Middle Devonian parathuramminid and earlandiid foraminifers from shallow marine carbonates of the Carnic Alps (Austria). Journal of Paleontology 92(3), 336-372. DOI 10.1017/jpa.2017.127

Walch, J.E.I. 1771. Die Naturgeschichte der Versteinerungen zur Erläuterung der Knorrischen Sammlung von Merkwürdigkeiten der Natur, Dritter Theil. 235 pp. Nürnberg, Felsecker.

Weber, V.N. 1937. Trilobites of the Carboniferous and Permian system of USSR. 1. Carboniferous trilobites. Palaeontology of USSR Monographs 71, 1-159. [in Russian with English summary]

Weiner, T., Brauckmann, C. Poukarová, H., Rak, Š. \& Kalvoda, J. 2012. Preliminary report on the new findings of Mississippian trilobites in the Březina Formation (Moravian Karst, Czech Republic). Geologické výzkumy na Moravě a ve Slezsku 19(1-2), 125-129. DOI 10.5817/GVMS2012-1-2-125
Weiner, T., Kalvoda, J., Müller, P. \& Poukarová, H. 2014. New data on Mississippian trilobites from the MoravianKarst (Czech Republic). Abstract Volume, $4^{\text {th }}$ International Palaeontological Congress Mendoza, 865.

Weiner, T., Poukarová, H. \& Viktorýn, T. 2018. A new find of scutelluid trilobite pygidium from the upper Frasnian of the Šumbera area near Brno-Líšeň (Moravian Karst, Czech Republic). Geoscience Research Reports 51(2), 121-125. DOI 10.3140/zpravy.geol.2018.28

Weinerová, H., Hron, K., BÁbeK, O., Šimíček, D. \& Hladil, J. 2017. Quantitative allochem compositional analysis of Lochkovian-Pragian boundary sections in the Prague Basin (Czech Republic). Sedimentary Geology 354, 43-59. DOI 10.1016/j.sedgeo.2017.04.002

Weller, J. M. 1936. Carboniferous trilobite genera. Journal of Paleontology 10(8), 704-714.

Whittington, H.B \& Kelly, S.R.A. 1997. Morphological terms applied to trilobita, 313-329. In KAESLER, R.L. (ed.) Treatise on Invertebrate Paleontology. Part 0. Arthropoda 1. Trilobita, revised, 1: Introduction, Order Agnostida, Order Redlichiida. Geological Society of America, Boulder and University of Kansas Press, Lawrence.

Woodward, H. 1883-1884. A monograph of the British Carboniferous trilobites. $86 \mathrm{pp}$. Palaeontographical Society, London.

Woodward, H. 1894. Note on a collection of Carboniferous trilobites from the banks of the Hodder, near Stonyhurst, Lancashire. Geological Magazine 1, 484-489. DOI 10.1017/S0016756800143894

YuAn, J. \& XIANG, L. 1998. Trilobite fauna at the DevonianCarboniferous boundary in South China (S-Guizhou and N-Guangxi). National Museum of Natural Science, Special Publication 8, 1-281.

Zandkarimi, K., Najafian, B., Vachard, D., Bahrammanesh, M. \& VAZIRI, S.H. 2014. Latest Tournaisian-late Viséan foraminiferal biozonation (MFZ8-MFZ14) of the Valiabad area, northwestern Alborz (Iran): geological implications. Geological Journal 51, 125-142. DOI 10.1002/gj.2616

\section{Electronic supplement}

Quantitative microfacies analysis (point-count data); correlations between variables (carbonate components); PCA: factor-variable correlations (factor loadings), based on correlations. 